\title{
A comprehensive and densely sampled map of shear-wave azimuthal anisotropy in the Aegean-Anatolia region
}

Anne PAUL ${ }^{1}$, Hayrullah KARABULUT ${ }^{2}$, Ahu Kömec MUTLU², and Gwénaëlle SALAÜN ${ }^{1}$

${ }^{1}$ Institut des Sciences de la Terre, Université Joseph Fourier - Grenoble 1, CNRS, BP 53, 38041 Grenoble Cedex, France

${ }^{2}$ Bogazici University, Kandilli Observatory and Earthquake Research Institute, 36684, Cengelkoy Istanbul, Turkey

Paper accepted for publication in Earth Planet. Sci. Lett., December 2013, doi: 10.1016/j.epsl.2013.12.019

Keywords: Seismic anisotropy; Anatolia-Aegean region; SKS wave; Upper mantle structure; Mantle flow 


\begin{abstract}
A better understanding of what drives surface motion in the rapidly deforming AegeanAnatolia region requires the comparison of mantle circulation models with reliable and densely spaced seismic anisotropy data. We present a new set of 4279 high-quality splitting data of core-refracted shear waves measured at 216 permanent and temporary broadband seismic stations in Turkey and Greece, and their neighboring countries. When combined with previously published observations, our dataset provides unprecedented dense spatial coverage of the area. The delay time between the fast and slow shear waves is highest in the northern Aegean Sea and northwestern Anatolia (average, $1.5 \pm 0.4 \mathrm{~s}$ ) and lowest in the southern Aegean Sea (average, $0.6 \pm 0.4 \mathrm{~s}$ ). The fast-wave polarization axes are oriented NE-SW over most of Anatolia and the northern Aegean Sea. These show steady counterclockwise rotation of $1^{\circ}$ per degree of longitude from eastern Anatolia to the northern Aegean. The only exceptions to this uniform pattern are NNW-SSE to NW-SE orientations in mainland Greece, and NW-SE orientations in the southwestern corner of Anatolia. The overall anisotropy pattern can be explained by instantaneous density-driven mantle flow with additional local effects, such as slab rollback in the Aegean Sea and a slab window beneath southwestern Anatolia.
\end{abstract}




\section{Introduction}

The question of the engine of the deformation in regions of active continental collision is still a major issue in geodynamics, such as for the Alpino-Himalayan belt. It is unclear, in particular, whether the main driving force for lithospheric strain originates at the plate edges through ridge push and slab pull, or through basal drag due to mantle flow. In the first case, the asthenosphere mainly accommodates the strain applied from above, while in the second case, the asthenosphere has an active part in dragging the lithosphere in the direction of the mantle flow. In a study on plate driving forces, Forte (2011) reviewed the contributions of whole-mantle tomography-based convection models in terms of our understanding of the role of mantle flow for plate circulation. However, Forte (2011) also indicated that the imperfect seismic imaging of mantle heterogeneity and the poor understanding of the causes of heterogeneity lead to two different views as to which mantle-convection-induced forces drive lithosphere motions. The most commonly accepted model ascribes a major part to the buoyancy forces induced by subducted slabs (e.g., Richter, 1973; Conrad and LithgowBertelloni, 2004; Faccenna et al., 2013a). In the second view, mantle upwelling in plumes is required in combination with subduction pull or suction to explain the surface motions (e.g., Turcotte and Oxburgh, 1967; Forte et al., 2009; Becker and Faccenna, 2011; Faccenna et al., 2013b).

Along with the Andes, the Alpino-Himalayan collisional belt is the best region for testing hypotheses relating to which forces drive active surface deformation while continental collision induces strong resistance (Becker and Faccenna, 2011). We focus here on the eastern Mediterranean, where geodetic velocity maps document the rapid westwards extrusion of Anatolia away from the Arabia plate indenter (McClusky et al., 2000; Reilinger et al., 2006). The Arabia push was initially considered as the main force driving the relative motion of Anatolia with respect to Eurasia, with the consequent localization of shear on the North Anatolian fault (e.g., Dewey and Şengör, 1979; Armijo et al., 1999). The geodetic data of Reilinger et al. (2006) show, however, that there is no fault-normal convergence on the East Anatolian fault that marks the boundary between Anatolia and Arabia, which indicates that the Arabia push is not the cause of the present motion of Anatolia. Moreover, abundant tectonic and petrologic data document strong back-arc spreading into the Aegean Sea, due to the retreat of the Hellenic trench since the early Miocene (Le Pichon and Angelier, 1979, 1981; Lister et al., 1984; Brun and Faccenna, 2008; Jolivet et al., 2013). Based on this evidence, the fast retreat of the Hellenic trench and the associated slab pull are considered to be the main forces that drive the westwards motion of the Anatolia microplate. Body forces due to differences in gravitational potential energy between the Anatolian plateau and the Aegean Sea might also contribute significantly to the deformation of the upper crust of Anatolia (Özeren and Holt, 2010). In contrast, with these edge and body force models, Le Pichon and Kreemer (2010) and Faccenna and Becker (2010) have claimed that basal drag by mantle flow is required to drive the surface motion in the eastern Mediterranean. Le Pichon and Kreemer (2010) argued that a counterclockwise asthenospheric flow is required in addition to the Hellenic slab pull, to force the circular pattern of the present-day surface motion from the Levant to Arabia, Anatolia and the Aegean. They proposed two causes for this asthenospheric circulation: toroidal flow induced at the eastern edge of the Hellenic- 
Cyprus subduction zone by slab rollback, and asthenospheric rise below the East Anatolian plateau. Faccenna and Becker (2010) computed the three-dimensional spherical mantle flow in the Mediterranean region that was driven by density anomalies inferred from seismic tomography and by motion of the Nubia, Arabia and Eurasia plates. They concluded that for the motion of Anatolia, the upper mantle flow driven by the negative buoyancy of the highdensity Hellenic slab has about an equal role to that of the Arabia push. The next step towards better understanding of the engine of the Anatolia motion was a comparison of the available mantle flow models with the seismic anisotropy, which is the only direct indicator of mantle strain (e.g. Faccenna et al., 2013b).

Seismic anisotropy of the upper mantle results from the lattice-preferred orientation (LPO) of intrinsically anisotropic olivine crystals (Nicolas and Christensen, 1987; Mainprice et al., 2000). The relation between LPO and strain depends on temperature, pressure, deviatoric stress, melt, and water content (Karato and Jung, 1998), although in most cases the orientation of the fast-wave velocity coincides with the large axis of the finite-strain ellipsoid (Ribe, 1992). Azimuthal anisotropy (with a horizontal fast-velocity axis) is measured from the birefringence of core-refracted shear waves (mostly SKS) or the azimuthal dependence of surface-wave phase velocity (see e.g., Montagner and Tanimoto, 1991; Silver, 1996; Savage, 1999). Surface-wave-based azimuthal anisotropy data are in good agreement with shear-wave splitting data when these latter are spatially averaged to account for the longer wavelength of the surface-wave tomography (Wüstefeld et al., 2009; Becker et al, 2012). As we are interested in imaging mantle anisotropy at high lateral resolution, we focused here on the shear-wave splitting data. When shear waves propagate through an anisotropic medium, they split into two quasi-S waves, with the polarization direction of the fast wave giving the fastvelocity direction, while the delay time between the slow and fast split waves is a function of the anisotropy strength.

In the Mediterranean region, observations of splitting of core-refracted phases have been key arguments in support of, e.g., mantle flow around the Eurasian slab in the Western Alps (Barruol et al., 2011), toroidal flow induced by slab rollback around the Calabrian subduction (Civello and Margheriti, 2004) and in the Gibraltar arc (Diaz et al., 2010). In the Aegean-Anatolia region, a number of studies have been published on splitting observations in the Aegean Sea and mainland Greece (Hatzfeld et al., 2001; Evangelidis et al., 2011; Olive et al., 2011), in north-central Anatolia (Biryol et al., 2010), and in eastern Anatolia (Sandvol et al., 2003). These have documented NE-SW fast-polarization orientations, with time delays of $1.0 \mathrm{~s}$ to $1.5 \mathrm{~s}$ in Anatolia and northern Aegean, smaller delays (0.0-0.5 s) in the southern Aegean, and N-S fast-wave orientations with small delays in mainland Greece. Although their observations show similar trends, the above-cited studies have proposed relatively different hypotheses for the origin of the anisotropy. Based on the coincidence of the fast orientation with the orientation of recent and present-day maximum strain revealed by geodesy and seismotectonics in the Aegean back-arc, Hatzfeld et al. (2001) proposed that the uppermost mantle (the lithosphere and part of the asthenosphere) and the upper crust of the Aegean have undergone vertically coherent deformation. Evangelidis et al. (2011) relied on their more precise and denser observations in the same region of the Aegean and mainland Greece, to conclude that there is trench-normal mantle flow induced by subduction rollback in the back-arc region, and trench-parallel mantle flow in mainland Greece. Finally, the latest 
and even more detailed observations of Olive et al. (2011) provide arguments for trenchnormal flow associated with trench retreat in the sub-slab region close to the trench and in the back-arc, while trench-parallel fast orientations above the corner of the mantle wedge are attributed to a thin layer of serpentine located above the subducting slab. Although they observed very similar anisotropy patterns with uniform NE-SW trending fast axes, Sandvol et al. (2003) and Biryol et al. (2010) disagreed on the causes. According to Biryol et al. (2010), anisotropy in central Anatolia is due to asthenospheric flow exerted by rollback of the Hellenic and Cyprus subductions, while Sandvol et al. (2003) explain their eastern Anatolia measurements as the vector difference between the absolute motion of the Eurasian lithosphere and a NE or SW directed flow in the asthenosphere.

Additional data on seismic anisotropy of the uppermost mantle beneath the AegeanAnatolia region were provided by the Pn tomography of Mutlu and Karabulut (2011). They documented strong and rapid changes in the amplitude of anisotropy and in the orientation of the fast-velocity axis. In the north and central Aegean, the fast Pn axis is trench-normal, parallel to the fast-polarization orientation measured from SKS waves by Hatzfeld et al. (2001) and Evangelidis et al. (2011). In Anatolia, fast Pn orientations are highly variable and they coincide poorly with the fairly homogeneous NE-SW fast-polarization orientations of Sandvol et al. (2003) and Biryol et al. (2010).

No shear-wave splitting measurements are available in the key regions of western and southern Anatolia. The present study aims to fill these gaps and to provide a comprehensive dataset of shear-wave splitting measurements with homogeneous and dense coverage from eastern Anatolia to western Greece. We confirm the widespread NE-SW orientation of the fast-velocity axis in Anatolia and the northern Aegean Sea, with the single exception in southwest Anatolia, where fast orientations trend NW-SE. We then compare the anisotropy data with the upper mantle S-wave velocity model of Salaün et al. (2012), and with the available models of mantle flow.

\section{SKS splitting data}

The new permanent broadband networks of Turkey and Greece provide high-quality seismic records over the broad area of interest to this study. To obtain uniform and dense spatial coverage of $60 \mathrm{~km}$ to $80 \mathrm{~km}$ spacing from mainland Greece to central Anatolia, we initiated the SIMBAAD (Seismic Images of the Mantle Beneath the Aegean-Anatolia Domain) project and installed temporary broadband stations for two years (2007-2009) in Turkey, Greece and southern Bulgaria (Salaün et al., 2012). Altogether the dataset includes records of 207 broadband seismic stations in the area $\left[34-43^{\circ} \mathrm{N} ; 19-45^{\circ} \mathrm{E}\right]$, with unprecedented spatial coverage.

We used the SplitLab software of Wüstefeld et al. (2008) to process the records of core-refracted SKS phases. As well as being easy to use, SplitLab has the advantage of combining two different methods for the estimation of splitting parameters from records of individual events: the rotation-correlation (RC) method of Bowman and Ando (1987), and the coherence method (SC) of Silver and Chan (1991). Both methods perform a grid search for the splitting parameters that best correct the seismogram for the effect of anisotropy, that is linearize the particle motion. The RC method searches for the parameters that maximize the 
cross-correlation coefficient between the trial rotated components, while the SC method searches for the parameters that minimize energy on the trial transverse component. SplitLab thus provides reliable estimates of the delay time, $\delta$ t, between the two split quasi-S waves and the polarization azimuth $\Phi$ of the fast split wave, even for weak anisotropy (Wüstefeld et al., 2007). Moreover, the quality of the measurements can be quantitatively assessed by comparing the values of $\Phi$ and $\delta$ t provided by the two methods (Wüstefeld et al., 2007). As a whole, we obtained 2247 good and fair-quality non-null measurements, and 2032 good and fair null measurements, from records of 473 events with magnitude between 5.8 and 7.6, at 216 stations (see maps in Supplementary Information Figure S1). The number of good and fair non-null measurements per station ranges from 1 to 97 with an average of 20 (see Supplementary Information Table S1).

Figure 1 shows a map of the splitting parameters averaged according to the stations, combined with the data of Hatzfeld et al. (2001), Sandvol et al. (2003), Biryol et al. (2010) and Evangelidis et al. (2011), as well as data from adjacent countries, which were retrieved from the splitting database gathered by Wüstefeld et al. (2009) (http://www.gm.univmontp2.fr/splitting/DB/). Overall, the agreement of our data (Fig. 1, red) with previously published data (Fig. 1, blue) is good in the regions where they coincide. As all four previous studies included thorough discussions on data quality, and particularly Biryol et al. (2010), we will not go into much detail on this topic (see Supplementary Information Table S1, Figs. S2, S3). With up to eight years of records from a few permanent stations, we had the unique opportunity to check the variations of the splitting parameters with the polarization direction of the incoming S wave. Indeed, measurements from different events can be averaged for a given station only when back-azimuthal variations are weak, which indicates that the anisotropy is localized in a single layer with a horizontal symmetry axis (Silver and Savage, 1994). The back-azimuthal coverage is, however, far from uniform, with most events concentrated in E-NE and W back-azimuths (see Supplementary Information Fig. S1). Considering this incomplete back-azimuthal coverage and the measurement uncertainties, we conclude that the most reliable model explaining our observations is the simplest one, with anisotropy concentrated in a single layer (see Supplementary Information Fig. S4).

Figure 1 shows the relatively uniform NE-SW orientations of the fast shear-wave velocity axes over most of Anatolia and the northern Aegean. The variations of $\Phi$ with longitude that are shown in Figure 2a show a small, but regular, counterclockwise rotation with decreasing longitude from $\sim 50^{\circ}$ at $45^{\circ} \mathrm{E}$ in eastern Anatolia, to $\sim 21^{\circ}$ at $24^{\circ} \mathrm{E}$ in the north Aegean. The azimuth of the fast axis then changes suddenly to the NNW-SSE orientation (Fig. 1), to give negative azimuths (Fig. 2a) at the stations in mainland Greece, while the delay times shown in Figure $2 \mathrm{~b}$ decrease from $1.5 \pm 0.4 \mathrm{~s}$ in the northern Aegean to $0.9 \pm 0.5 \mathrm{~s}$ in mainland Greece. Further west, the fast polarizations are back to the NE-SW orientations at four stations along the western coast of Greece and on the Ionian Islands (Fig. 1). Figure 1 also shows that fast axes measured in the southernmost Italian peninsula have similar NE-SW orientations as for westernmost Greece, in the northern Aegean, and over most of Anatolia. From Evvia and the Cyclades to Crete, the splitting is weak ( $0.6 \pm 0.4 \mathrm{~s})$ or null, with mostly NE-SW fast polarizations. In Anatolia, the only exception to the uniform NE-SW fast polarization is observed at a group of stations in southwest Anatolia; more precisely, north and northwest of the bay of Antalya (Fig. 1). These NW-SE fast-polarization 
orientations can be seen clearly in Figure $2 \mathrm{a}$ at longitudes from $29^{\circ} \mathrm{E}$ to $32^{\circ} \mathrm{E}$ with azimuths of $-25^{\circ}$ to $-60^{\circ}$, which are almost perpendicular to orientations observed elsewhere in Anatolia. Their delay times are close to the average delay time of $1.3 \pm 0.4 \mathrm{~s}$ for stations in Anatolia (Fig. 2b).

\section{Discussion: origin of the observed azimuthal anisotropy}

\subsection{Anisotropic source layer}

Endrun et al. (2011) measured two-station phase velocities of Rayleigh waves in the Aegean Sea and mainland Greece, and inverted them for azimuthally anisotropic phase velocity maps. They found 3.5\% maximum anisotropy in the Cyclades at $12 \mathrm{~s}$ to $18 \mathrm{~s}$ period, sampling mostly the middle and lower crust. This gives an upper limit of $0.2 \mathrm{~s}$ to $0.4 \mathrm{~s}$ for the crustal contribution to the delay time of the split SKS wave, if a 3.5\% uniform anisotropy is assumed in a $25-\mathrm{km}$-thick to $40-\mathrm{km}$-thick crust. It is therefore possible that crustal anisotropy contributes significantly to the few $(16 \%)$ station-averaged splitting measurements with delay time smaller than $0.5 \mathrm{~s}$, which are almost all located in mainland Greece and southern Aegean. Conversely, the $1 \mathrm{~s}$ to $2 \mathrm{~s}$ delay times observed in other areas mostly have a mantle origin.

Considering the large delay times measured at north Aegean stations ( $>1 \mathrm{~s})$, Hatzfeld et al. (2001) proposed that the lithospheric mantle and possibly the asthenosphere are anisotropic. Using an enhanced dataset in the same region, Evangelidis et al. (2011) concluded that anisotropy in the Aegean originates from flow in the mantle wedge. In Anatolia, Sandvol et al. (2003) and Biryol et al. (2010) concluded that the spatially homogeneous splitting pattern can only be explained by an asthenospheric source, as the lithospheric mantle is expected to undergo significant lateral changes in thickness (there is no lithospheric mantle in eastern Anatolia according to Sengör et al., 2003) and in strain state (across the North Anatolian Fault or the East Anatolian Fault) in their study regions. A stronger argument for an asthenospheric origin of the observed splitting is the presence of a widespread low-velocity zone between $80 \mathrm{~km}$ and $200 \mathrm{~km}$ deep beneath most of Anatolia and the northern Aegean in the shear-wave velocity model of Salaün et al. (2012), which argues for a thinned lithosphere. Therefore, over most of the study area, the lithospheric mantle is too thin to provide a significant contribution to the observed anisotropy. As a 110-km-thick layer with $4 \%$ anisotropy is required to induce SKS splitting with a delay time of $1 \mathrm{~s}$, the lowvelocity zone imaged by Salaün et al. (2012) (and interpreted as a mantle wedge) is a good candidate for the anisotropic layer.

To obtain a comprehensive view of the lateral variations of the splitting parameters, we projected each single measurement (i.e., for a single event-station couple) to the ray piercing point at $150 \mathrm{~km}$ in depth, which is about the expected depth of the anisotropic layer (Fig. 3). We then computed vector averages of the projected observations within the Fresnel zone of a SKS wave with 15-s dominant period, which has a radius of $\sim 150 \mathrm{~km}$ at $150 \mathrm{~km}$ in depth, according to the sensitivity kernels computed by Monteiller and Chevrot (2011). The spatial averaging also takes into account the station-averaged anisotropy parameters of previous investigations (Fig. 1, blue), although with a stronger weight than individual observations, and no lateral shift, as these are not related to a single event. The resulting fastwave azimuth map of Figure 3a has positive values (NE-SW orientations) over most of 
Anatolia, Cyprus and the Aegean, with a slow decrease of $\Phi$ from east to west, negative azimuths (NNW-SSE to NW-SE orientations) in southwestern Anatolia and mainland Greece, and positive azimuths again west of mainland Greece. The strongest time lags are measured in western Anatolia and the northern Aegean, while mainland Greece and the southern Aegean have weak anisotropy (Fig. 3b).

In summary, shear-wave splitting observations show a remarkably uniform pattern, with time delays larger than $1 \mathrm{~s}$ and NE-SW oriented fast axes over most of the study region from eastern Anatolia to the western coast of Greece. The main departures from this pattern are the NNW-SSE to NW-SE fast-axis orientations of mainland Greece and southwestern Anatolia, and the small lag times of the south Aegean Sea. From eastern Anatolia to the northern Aegean, the fast-polarization azimuths undergo a steady counterclockwise rotation of $1^{\circ}$ per degree of longitude (Fig. 2a). This anisotropy pattern is surprisingly simple in comparison with, for example, the highly variable surface strain computed from geodetic velocities (Le Pichon and Kreemer, 2010), or the intricate seismic-wave velocity structure of the underlying mantle (Piromallo and Morelli, 2003; Biryol et al., 2011; Salaün et al., 2012). Such a simple anisotropy pattern requires a single explanatory model for the entire region. As the origin of anisotropy in the Aegean area has already been investigated in previous studies, we first concentrate on this area and discuss whether the proposed models apply to Anatolia.

\subsection{Causes of anisotropy in the Aegean Sea and mainland Greece}

As indicated by Hatzfeld et al. (2001), Jolivet et al. (2009) and Evangelidis et al. (2011), the fast-velocity orientation in the back-arc region is very close to the direction of the maximum finite extension deduced from geodetic measurements, and to the direction of stretching lineations in the middle and lower crust exhumed in the metamorphic core complexes of the Aegean. Jolivet et al. (2009) concluded from this correlation that the crust and mantle of the Aegean are stretched in the same direction, and that this deformation is driven from below by the rollback of the Hellenic slab.

Trench-normal fast-velocity orientations in the Aegean back-arc were also observed by Olive et al. (2011) using both SKS records and S splitting data from intermediate-depth earthquakes recorded by a dense seismic array in mainland Greece. They concluded that the complex anisotropic signature of the Hellenic subduction, with trench-normal fastpolarization orientations in the very near-trench, and back-arc regions and trench-parallel orientations in the near-trench, is best explained by trench-normal strain induced by trench retreat both below and above the slab, and serpentinization in a thin layer above the slab. We have very similar observations at a less-dense spatial sampling, but over a broader area. In Figure 3a, the near-trench area with the trench-parallel fast axes of Olive et al. (2011) corresponds to the blue area that covers most of mainland Greece and the westernmost Aegean. The corresponding delay times are small (Fig. 3b), as observed by Olive et al. (2011). Figure $3 \mathrm{a}$ also documents the very near-trench area along the western coast of Greece with trench-normal orientations and lag times of $\sim 1 \mathrm{~s}$. The delay times increase abruptly from $\sim 0.5 \mathrm{~s}$ in the south Aegean to $>1.5 \mathrm{~s}$ in the north (Fig. 3b). The boundary between the two regions is almost parallel and is located $100 \mathrm{~km}$ to the north of the $170-\mathrm{km}$ isodepth of the Aegean Wadati-Benioff zone mapped by Papazachos et al. (2000) and shown as the thick dot-and-dash black line in Figure 3b. We speculate that this abrupt strengthening of 
anisotropy is related to a deep slab kink that induces a strong increase in the thickness of the mantle wedge, which is the likely source of anisotropy in the Aegean back-arc. This hypothesis contradicts the inference of Sodoudi et al. (2006) that the slab depth is roughly constant at $200 \mathrm{~km}$ to $220 \mathrm{~km}$ beneath the northern Aegean. Their receiver-function result was however questioned by the surface-wave tomography of Salaün et al. (2012), which documents a slab top surface that deepens to more than $300 \mathrm{~km}$ beneath Lesbos Island (Salaün, 2011). This last view agrees better with the large lag times that we observe in the northern Aegean.

One of the new observations provided by the present study is the set of NW-SE fastpolarization orientations in southwestern Anatolia (Fig. 3a). Figure 4a shows the uniformly sampled anisotropy vector field calculated by averaging the splitting observations in the Fresnel zone of the SKS wave at $150 \mathrm{~km}$ in depth. This field is superimposed on the map of shear-wave velocity perturbations at $150 \mathrm{~km}$ in depth that was constructed by Salaün et al. (2012) from the inversion of the Rayleigh wave phase-velocity measurements. The highvelocity anomalies are interpreted by Salaün et al. (2012) as traces of the Hellenic slab in the west and traces of an Anatolian or Cyprean slab beneath central Anatolia. The Vs perturbation map also documents two low-velocity zones beneath western Anatolia and the north Aegean Sea, and beneath central Anatolia. Salaün (2011) picked the top surface of the high-velocity anomalies in the three-dimensional shear-wave velocity model of Salaün et al. (2012), and showed that the high-velocity slabs have a complex geometry, with slab windows characterized by low velocities. A map view of these slab breaks and windows is shown in Figure $4 \mathrm{~b}$, superimposed on the fast-polarization azimuths of Figure 3a. This map illustrates the striking spatial coincidence between the slab window documented by Salaün et al. (2012) beneath western Anatolia and the western boundary of the area of NW-SE fast split orientations. As this slab window is located at the eastern edge of the Hellenic slab, we interpret the anomalous NW-SE fast-wave azimuths of southwestern Anatolia as the result of toroidal flow from the subslab region through the slab window, allowing for the retreat of the slab, as modeled by Funiciello et al. (2006) and Faccenda and Capitanio (2012).

\subsection{Causes of the anisotropy in Anatolia}

In this section, we discuss the possible causes of the anisotropy in the Anatolian mantle, including the hypothesis of trench-normal flow in the mantle wedge proposed for the northern Aegean.

\subsubsection{Lithosphere stretching and absolute plate motion}

The Aegean Sea is the only part of the study region where the orientations of the present-day maximum extension (in the northern Aegean) or the present-day velocities (in the southern Aegean) coincide with the observed orientations of the fast velocity. In westernmost Anatolia, where stretching is at present stronger than in the Aegean, according to Aktug et al. (2009) and Floyd et al. (2010), the direction of the maximum extension (N-S) and the absolute plate motion (APM) velocities in a no net-rotation reference frame (E-W to ENEWSW) are both oblique to the NE-SW orientations of the fast axes. This misfit is illustrated in Supplementary Information Figure S5, which compares the APM velocity vectors of the global strain rate map APM-1 model (Kreemer, 2009) with the observed anisotropy field. In 
the southwestern corner of Anatolia, where the orientations of the fast polarization are NWSE, the surface strain is negligible or the maximum extension is E-W (Aktug et al., 2009), while the APM velocity orientations vary between ESE-WNW and ENE-WSW. In most of central Anatolia, except along the North Anatolian Fault, the surface strain is weak and the APM velocities are E-W, while the fast-velocity axis is uniformly oriented NE-SW.

In summary, the APM velocity field and the present-day surface-strain pattern are too laterally variable to explain the uniform pattern of mantle anisotropy in Anatolia. Hence, the observed anisotropy is not induced by simple shear due to the motion of the lithosphere relative to the less viscous asthenosphere. Sandvol et al. (2003) explained the SKS splitting observed in eastern Anatolia by a combination of mantle flow in the asthenosphere and platedriven shear at the lithosphere-asthenosphere boundary, following the model of Silver and Holt (2002). We tested this hypothesis by computing a set of mantle flow fields that would combine with the complex APM velocity field of Supplementary Information Figure S5 to give the observed anisotropy pattern. As the fast axes have a roughly uniform orientation, the computed mantle flow fields mimic the complexity of the APM velocity field. For example, the flow field has to compensate for the rotation of the APM velocities with longitude, which is much faster than the rotation of the fast polarization orientations (from $45^{\circ} \mathrm{E}$ to $25^{\circ} \mathrm{E}: 60^{\circ}$ counterclockwise rotation for the APM and $20^{\circ}$ for the polarization). Therefore, we consider that this model is too ad hoc to be favored.

\subsubsection{Slab rollback}

Biryol et al. (2010) attributed the NE-SW fast-polarization orientations of north-central Anatolia to the southwestwards directed asthenospheric flow induced by the rollback of the Hellenic and Cyprus slabs. In their model, the large delay times measured at the western stations of the NAF array (west of $34^{\circ} \mathrm{N}$ ) are due to the fast retreat of the Aegean trench, while the eastern stations have smaller delay times under the effects of the slowly retreating Cyprus trench. This hypothesis is similar to that which Jolivet et al. (2009) and Evangelidis et al. (2011) proposed for the Aegean. We, however, believe that the hypothetical rollback of the Cyprean trench is so much weaker than the well-documented fast retreat of the Hellenic trench that it can hardly affect the mantle flow beneath Anatolia. While back-arc extension in the Aegean and westward extrusion of Anatolia along the North Anatolian fault are attributed to the rollback of the Hellenic slab, the only record of extension in central Anatolia that might be attributed to rollback of the southern Anatolian subduction is the exhumation of highpressure rocks along the Izmir-Ankara suture zone that was dated at $60 \mathrm{Ma}$ by Pourteau et al. (2008).

The open question is now whether the rollback of the narrow Hellenic slab can induce trench-normal SW-directed mantle flow beneath central and eastern Anatolia, more than 1000 $\mathrm{km}$ away from its eastern edge. According to the laboratory models of mantle flow around retreating subductions by Funiciello et al. (2006), the size of the toroidal cell induced around the slab edge is 2 to 3 times the slab's width in the direction perpendicular to the trench. As the retreating Hellenic slab is wider than $500-600 \mathrm{~km}$, the area where mantle flow may be disturbed by slab rollback is at least 1000 to $1500 \mathrm{~km}$ wide. It therefore includes most of the study area. 


\subsubsection{Mantle flow}

The relatively uniform NE-SW orientation of the fast split axes is not compatible with the suggestion by Le Pichon and Kreemer (2010) that a regional-scale counterclockwise asthenospheric flow around the eastern edge of the Hellenic slab drives the westwards motion of Anatolia from below. We do image toroidal flow at the eastern edge of the slab, but to a much smaller spatial extent than in the Le Pichon and Kreemer (2010) hypothesis.

The fast-polarization orientations should, however, be compared to the directions of the largest finite-strain axis computed from mantle flow, and not directly with flow directions (Ribe, 1992). Becker et al. (2003) computed finite strain derived from global mantle circulation models, and they showed that the fit of surface-wave derived azimuthal anisotropy to computed LPO orientations is satisfactory for most of the oceans, but not for the continents. They attributed the observed misfit to the complex history of strain for continents, where anisotropy can be frozen-in from old deformation episodes. As discussed above, this explanation does not stand for the Aegean-Anatolia region where the lithosphere is thinned. Another possible explanation is that the global flow model does not account for regional features, such as small-scale mantle heterogeneity. Indeed, Faccenna and Becker (2010) introduced regional-scale structural complexities into their global density and plate-motiondriven mantle flow model that was focused on the Mediterranean region. Recently, Faccenna et al. (2013b) added the calculation of synthetic anisotropy to their mantle circulation model, and compared its output to published shear-wave splitting data in the Middle East, including the Aegean and Anatolia. In their first model, mantle circulation was only produced by uppermantle high-density anomalies associated with Wadati-Benioff zones, including the Hellenic subduction. This demonstrates that suction by the high-density Hellenic slab induces NE-SWoriented fast split axes in central Anatolia, which is in agreement with observations. This broad-scale model, however, fails to explain the complex anisotropy pattern of the Aegean, and more important for the present discussion, it gives E-W fast-polarization orientations in eastern Anatolia. In the second model of Faccenna et al. (2013b), lower mantle density anomalies are added to the subduction zone anomalies to combine large-scale convection driven by the African superswell, with regional-scale convection driven by the Hellenic slab. The fast split orientations measured in the western Aegean and central and eastern Anatolia are matched better by this model, which shows that density-driven westwards-directed mantle flow beneath Anatolia induced by the combination of upwelling from the African superswell and downwelling in the Aegean explains NE-SW fast split orientations in Anatolia.

Another mantle circulation model was provided by Forte et al. (2009), who used a different global seismic tomography from that of Facenna et al. (2013b), and different flow modeling assumptions. For their model that best matches our splitting data, a map of maximum horizontal stretching induced by mantle circulation at $170 \mathrm{~km}$ beneath the eastern Mediterranean is shown in Figure 5 (blue lines). The regional direction of maximum horizontal stretching is oriented NE-SW, close to the dominant orientation of the fast-wave axes, at least in the Mediterranean Sea south of Anatolia and Crete, and north of the Caspian Sea. However, the stretching related to mantle flow is mostly N-S beneath Anatolia, oblique to the fast-polarization orientation. The change in maximum finite extension in the mantle circulation model can result from the deflection of flow by the high-density Hellenic and Cyprean slabs. The misfit between the output of the flow model and the SKS data might 
suggest that the density model used in Forte et al. (2009) is not correct for the AegeanAnatolia region. Another possible explanation for this mismatch is that fast split orientations should not be compared directly with maximum horizontal stretching, but with synthetic anisotropy data computed for the mantle LPO fabric inferred from mantle flow, as in Faccenna et al. (2013b), and following Becker et al. (2006).

The mantle circulation and the related synthetic anisotropy model of Faccenna et al. (2013b) is the best physical model available to date to explain the NE-SW fast-polarization orientations observed in Anatolia. This might be produced by mantle flow driven at large scales by the African superswell, and at regional scales by suction from the high-density Hellenic slab. Although the direct comparison of fast split orientations with maximum stretching might be too crude, the flow model by Forte et al. (2009) also shows that the largescale convection cell driven by the African swell and the Tethyan subductions results in a dominantly NE-SW maximum stretching direction close to our fast-polarization orientations. Another argument in favor of the pervasive character of the NE-SW orientation is the fit between our SKS splitting data and the azimuthal anisotropy data inferred by Debayle et al. (2005) from global surface-wave tomography (Supplementary Information Figure S6). Hence, we speculate that the large-scale mantle flow driven by the African swell combines with the regional-scale flow driven by the suction from the Hellenic slab high-density anomaly, which is probably augmented by trench-normal flow due to slab rollback, to induce almost uniformly oriented NE-SW fast split orientations from the Aegean to Anatolia. The progressive counterclockwise rotation of the fast-polarization axis from eastern Anatolia to the northern Aegean might result from the addition of the rollback-induced trench-normal flow when getting closer to the Hellenic subduction, while toroidal flow through the slab window beneath southwestern Anatolia explains the observed NW-SE fast split orientations. Conversely, the pervasive pattern of NE-SW orientations remains unperturbed by the weak, torn Anatolian (or Cyprean) slab imaged beneath central and eastern Anatolia by Salaün et al. (2012).

\section{Conclusions}

With more than 2200 new fair and good non-null SKS splitting measurements at 216 permanent and temporary seismic stations, and augmented with published data, our dataset covers the entire Aegean-Anatolia region with unprecedented spatial density. This good coverage has made it possible to construct maps of the anisotropy parameters, the fast split azimuth, and the delay time, which we have compared to the regional shear-wave velocity model computed by Salaün et al. (2012) from surface-wave records of the same seismic array.

Our data confirm the pervasive pattern of the NE-SW fast-axis orientations from the northern Aegean Sea to eastern Anatolia. The fast azimuths undergo steady counterclockwise rotation of $1^{\circ}$ per degree of longitude from eastern Anatolia to the northern Aegean. The only exceptions are in the vicinity of the Hellenic subduction, with very low delay times in the southern Aegean Sea, and N-S or NW-SE fast split orientations in mainland Greece and the southwestern corner of Anatolia. As in previous studies on shear-wave anisotropy in the same region, we favor the hypothesis of an asthenospheric source for the observed anisotropy, 
mainly because tomographic models document a pervasive low-velocity anomaly from $80 \mathrm{~km}$ to $200 \mathrm{~km}$ in depth, which is indicative of a thin mantle lithosphere (e.g., Salaün et al., 2012).

Shear stress induced by velocity gradients in the mantle flow are the most plausible source of the observed anisotropy, as shown by Faccenna et al. (2013b) in their models of instantaneous density-driven mantle flow. Among their other results regarding the engine of the plate motions, they document that global-scale mantle circulation and upwelling from the African superswell combine with regional-scale convection exerted by suction from the highdensity Hellenic slab, to give fast split azimuths that correctly match the observations in central and eastern Anatolia. We speculate that a better fit to anisotropy measurements in the Aegean region and western Anatolia would be obtained with a more realistic model of the Hellenic slab, which would include the slab window beneath southwestern Anatolia and the history of the trench retreat (Faccenda and Capitanio, 2012). This would help to confirm that the fast split azimuths turn progressively when they get closer to the Aegean, because of the increased influence of trench-normal flow due to slab rollback, and that the NW-SE orientations measured in southwestern Anatolia result from toroidal flow, and are thus further evidence of a slab window in this region. 


\section{Figure captions}

Figure 1. Map of the Eastern Mediterranean region showing the station-averaged splitting data from our analysis (red) and from previous studies (blue; from the Montpellier splitting database: http://www.gm.univ-montp2.fr/splitting/DB/). The average splitting results with a high level of confidence are plotted as thick red line segments (number of good or fair nonnull measurements $>3$; standard deviation on $\delta t<0.8 \mathrm{~s}$; standard deviation on $\Phi<25^{\circ}$ ), while others are plotted as thin red line segments. Ae: Aegean Sea; AF: Africa; AN: Anatolia; AR: Arabia; BAn: Bay of Antalya; Cr: Crete; Cyc: Cyclades; Cyp: Cyprus; EAF: East Anatolian Fault; EU: Eurasia; Ev: Evvia; Io: Ionian Islands; Ml. Greece: Mainland Greece; NAF: North Anatolian Fault.

Figure 2. Variations in the fast-wave polarization orientation (a) and the delay time (b) with longitude, for stations with latitudes between $34^{\circ} \mathrm{N}$ and $43^{\circ} \mathrm{N}$. Our good and fair stationaveraged measurements are plotted in red, with error bars. The data in the Montpellier splitting database gathered from different studies are plotted as blue-filled circles.

Figure 3. Maps of the fast-axis orientation $\Phi$ (a) and delay time $\delta \mathrm{t}(\mathrm{b})$ at $150 \mathrm{~km}$ in depth, calculated by projecting each individual observation from the station location to $150 \mathrm{~km}$ depth along the raypath of the incident wave, and averaging in the Fresnel zone of the SKS wave (see text for further explanations). Individual observations projected to depth are shown as gray and black sticks for fair and good observations, respectively. The published station means (thick black sticks) are projected vertically, as these are averages of measurements from different back-azimuths. To account for the non-uniform data quality when computing spatial averages, we applied weights of $0.5,1$ and 3 to the fair, good and published observations respectively. The thick dot-and-dash line in (b) is the isodepth of $170 \mathrm{~km}$ for earthquakes of the Wadati-Benioff zone of the southern Aegean, according to Papazachos et al. (2000).

Figure 4. Comparison of anisotropy maps with the data of surface-wave tomography of Salaün et al. (2012). (a) The interpolated SKS anisotropy vector field projected to $150 \mathrm{~km}$ in depth (black sticks with black-filled wedges, showing standard deviations in the fast-axis direction) is superimposed on the shear-wave velocity perturbations mapped at $150 \mathrm{~km}$ in depth by Salaün et al. (2012). (b) Our map of fast-wave polarization superimposed on the map of slab tears and slab windows picked by Salaün (2011), from their three-dimensional shear-wave velocity model. Plain thick black lines are major tears, while dotted lines are minor tears; gray-filled areas are slab windows.

Figure 5. Comparison of the average anisotropy vector field (red sticks) with the maximum horizontal stretching directions at $170 \mathrm{~km}$ in depth, computed from the mantle flow model of Forte et al. (2009) (blue sticks). 


\section{Acknowledgments}

We thank all the colleagues who helped us with the SIMBAAD temporary seismic experiment, in particular D. M. Childs, P. Hatzidimitriou and C. Papazachos. We also thank the staff of the seismological surveys of Turkey and Greece who installed the permanent broadband networks and made the data available for this study. Seismic instruments of the temporary experiment were provided by the Sismob-RESIF national pool (France). The database of the temporary experiment was prepared by C. Péquegnat and E. Bourova-Flin. We are grateful to the authors of the SplitLab software, A. Wüstefeld, G. Bokelmann and G. Barruol. Maps were created using the Generic Mapping Tools (Wessel \& Smith 1998). This work benefitted from enlightening discussions with many colleagues, in particular J-P. Brun, F. Capitanio, C. Faccenna, A. Forte, and L. Jolivet. Special thanks to A. Forte for computing the stretching directions displayed in Figure 5. Two anonymous reviewers helped improving the manuscript. Funding of project SIMBAAD was provided by Agence Nationale de la Recherche (France) under contract ANR-06-BLAN-0317. 


\section{References}

Aktug, B., et al., 2009. Deformation of western Turkey from a combination of permanent and campaign GPS data: Limits to block-like behavior, J. geophys. Res., 114, B10404, doi:10.1029/2008JB0060000.

Armijo, R., B. Meyer, A. Hubert, and A. Barka, 1999. Westward propagation of the North Anatolian fault into the northern Aegean: Timing and kinematics, Geology, 27(3), 267270.

Barruol, G., M. Bonnin, H. Pedersen, G.H.R. Bokelmann, and C. Tiberi, 2011. Belt-parallel mantle flow beneath a halted continental collision: The Western Alps, Earth Planet. Sci. Lett., 302, 429-438, doi: 10.1016/j.epsl.2010.12.040

Becker, T. W., J. B. Kellogg, G. Ekström, and R. J. O’Connell, 2003. Comparison of azimuthal seismic anisotropy from surface waves and finite strain from global mantle circulation models, Geophys. J. Int., 155, 696-714.

Becker, T. W., Chevrot, S., Schulte-Pelkum, V. and Blackman, D. K., 2006. Statistical properties of seismic anisotropy predicted by upper mantle geodynamic models. $J$. geophys. Res. 111, B08309.

Becker, T.W., and C. Faccenna, 2011. Mantle conveyor beneath the Tethyan collisional belt, Earth Planet. Sci. Lett., 310, 453-461, doi:10.1016/j.eps1.2011.08.021.

Becker, T.W., S. Lebedev, and M.D. Long, 2012. On the relationship between azimuthal anisotropy from shear wave splitting and surface wave tomography, J. geophys. Res., 117, B01306, doi:10.1029/2011JB008705.

Biryol, C.B., G. Zandt, S.L. Beck, A.A. Ozacar, H.E. Adiyaman, and C.R. Gans, 2010. Shear wave splitting along a nascent plate boundary: the North Anatolian Fault Zone, Geophys. J. Int., 181, 1201-1213, doi: 10.1111/j.1365-246X.2010.04576.x

Biryol, C.B., S. L. Beck, G. Zandt, and A. A. Özacar, 2011. Segmented African lithosphere beneath the Anatolian region inferred from teleseismic P-wave tomography. Geophys. J. Int., 184, 1037-1057, doi: 10.1111/j.1365-246X.2010.04910.x

Bowman, J. R., and M. Ando, 1987. Shear-wave splitting in the uppermantle wedge above the Tonga subduction zone, Geophys. J. R. Astr. Soc. 88, 25-41.

Brun, J. P., and C. Faccenna, 2008. Exhumation of high-pressure rocks driven by slab rollback, Earth planet. Sci. Lett., 272, 1-7.

Civello, S., and L. Margheriti, 2004. Toroidal mantle flow around the Calabrian slab (Italy) from SKS splitting, Geophys. Res. Lett., 31, L10061, doi:10.1029/2004GL019607.

Conrad, C.P., and C. Lithgow-Bertelloni, 2004. The temporal evolution of plate-driving forces: Importance of "slab suction" versus "slab pull” during the Cenozoic, J. geophys. Res., 109, B20407, doi: 10.1029/2004JB002991.

Debayle et al., 2005. Global azimuthal seismic anisotropy and the unique plate-motion deformation of Australia, Nature, 433, 509-512, doi :10.1038/nature03247.

Dewey, J.F. and Şengör, A.M.C., 1979. Aegean and surrounding regions complex multiplate and continuum tectonics in a convergent zone, Geol. Soc. Am. Bull., Part I, 90, 84-92.

Diaz, J., J. Gallart, A. Villasenor, F. Mancilla, A. Pazos, D. Cordoba, J.A. Pulgar, P. Ibarra, and M. Harnafi, 2010. Mantle dynamics beneath the Gibraltar Arc (western Mediterranean) from shear-wave splitting measurements on a dense seismic array, Geophys. Res. Lett., 37, L18304, doi:10.1029/2010GL044201. 
Endrun, B., S. Lebedev, T. Meier, C. Tirel, and W. Friederich, 2011. Complex layered deformation within the Agean crust and mantle revealed by seismic anisotropy, Nature geoscience, 4, 203-207, doi:10.1038/NGEO1065.

Evangelidis C.P., W-T. Liang, N.S. Melis, and K.I. Konstantinou, 2011. Shear wave anisotropy beneath the Aegean inferred from SKS splitting observations, J. geophys. Res., 116, B04314, doi:10.1029/2010JB0007884.

Faccenda, M., and F. A. Capitanio, 2012. Development of mantle flow seismic anisotropy during subduction-induced 3-D flow, Geophys. Res. Lett., 39, L11305, doi:10.1029/2012GL051988.

Faccenna, C., and Becker, T., 2010. Shaping mobile belts by small-scale convection. Nature, 465, 602-605, doi:10.1038/nature09064.

Faccenna, C., T.W. Becker, C.P. Conrad, and L. Husson, 2013a. Mountain building and mantle dynamics, Tectonics, 32, 80-93, doi:10.1029/2012TC003176.

Faccenna, C., T.W. Becker, L. Jolivet, and M. Keskin, 2013b. Mantle convection in the Middle East: Reconciling Afar upwelling, Arabia indentation and Aegean trench rollback, Earth planet. Sci. Lett., 375, 254-269, doi :10.1016/j.epsl.2013.05.043

Floyd, M.A., et al., 2010. A new velocity field for Greece : Implications for the kinematics and dynamics of the Aegean, J. geophys. Res., 115, B10403, doi :10.1029/2009JB007040.

Forte, A., 2011. Plate driving forces, in Encyclopedia of Solid Earth Geophysics, H.K. Gupta ed., Springer Science, p. 977-983.

Forte, A.M., R. Moucha, D.B. Rowley, S. Quéré, J.X. Mitrovica, N.A.Simmons, and S.P. Grand, 2009. Recent tectonic plate decelerations driven by mantle convection, Geophys. Res. Lett., 36, L23301, doi:10/1029/2009GL040224.

Funiciello, F., M. Moroni, C. Piromallo, C. Faccenna, A. Cenedese, and H. A. Bui, 2006. Mapping mantle flow during retreating suduction : Laboratory models analyzed by feature tracking, J. geophys. Res., 111, B03402, doi:10.1029/2005JB003792.

Hatzfeld, D., E. Karagianni, I. Kassaras, A. Kiratzi, E. Louvari, H. Lyon-Cean, K. Makropoulos, P. Papadimitriou, G. Bock, and K. Priestley, 2001. Shear wave anisotropy in the upper mantle beneath the Aegean related to internal deformation, $J$. geophys. Res., $106,30,737-30,753$.

Jolivet L., C. Faccenna, and C. Piromallo, 2009. From mantle to crust: Stretching the Mediterranean, Earth Planet. Sci. Lett., 285, 198-209, doi: 10.1016/J.eps1.2009.06.017

Jolivet, L., C. Faccenna, B. Huet, L. Labrousse, L. Le Pourhiet, O. Lacombe, E. Lecomte, E. Burov, Y. Denèle, J.-P. Brun, M. Philippon, A. Paul, G. Salaün, H. Karabulut, C. Piromallo, P. Monié, F. Gueydan, A. I. Okay, R. Oberhänsli, A. Pourteau, R. Augier, L. Gadenne, and O. Driussi, 2013. Aegean Tectonics: Strain localisation, slab tearing and trench retreat, Tectonophysics, 597-598, 1-33, doi:10.1016/j.tecto.2012.06.011

Karato, S.-I., and H. Jung, 1998. Water, partial melting and the origin of the seismic low velocity and high attenuation zone in the upper mantle, Earth Planet. Sci. Lett., 157, 193 - 207, doi:10.1016/S0012-821X(98)00034-X.

Kreemer, C, 2009. Absolute plate motions constrained by shear wave splitting orientations with implications for hot spot motions and mantle flow, J. geophys. Res., 114, B10405, doi:10.1029/2009JB006416 
Le Pichon, X., and J. Angelier, 1979. Hellenic arc and trench system - Key to the neotectonic evolution of the eastern Mediterranean area, Tectonophysics, 60(1-2), 1-42.

Le Pichon, X., and J. Angelier, 1981. The Aegean Sea, Phil. Trans. Roy. Soc. London, 300, 357-372.

Le Pichon, X., and C. Kreemer, 2010. The Miocene-to-Present kinematic evolution of the Eastern Mediterranean and Middle East and its implications for dynamics, Annu. Rev. Earth Planet. Sci., 38, 323-51, doi:10.1146/annurev-earth-040809-152419

Lister, G.S., G. Banga, and A. Feenstra, 1984. Metamorphic core complexes of Cordilleran type in the Cyclades, Aegean Sea, Greece, Geology, 12, 221-225.

Mainprice, D., G., Barruol, and W. Ben Ismail, 2000. The seimic anisotropy of the Earth's mantle: from single crystal to polycrystal, in Earth's Deep Interior. Mineral Physics and Tomography from the Atomic to the Global Scale, eds Karato, S.-I., Forte, A.M., Liebermann, R.C., Masters, G. and Stixrude, L., Geophysical Monograph, American Geophysical Union, Washington D.C., Vol. 117, pp. 237-264,

McClusky, S., et al., 2000. Global Positioning System constraints on plate kinematics and dynamics in the eastern Mediterranean and Caucasus, J. geophys. Res., 105(B3), 56955720, doi:10.1029/1999JB900351.

Montagner, J. P., and T. Tanimoto, 1991. Global upper mantle tomography of seismic velocities and anisotropies, J. geophys. Res., 96, 20337-20351.

Monteiller, V., and S. Chevrot, 2011. High-resolution imaging of the deep anisotropic structure of the San Andreas Fault system beneath southern California, Geophys. J. Int., 186, 418-446, doi:10.1111/j.1365-246X.2011.05082.x

Mutlu, A. K., and H. Karabulut, 2011. Anisotropic Pn tomography of Turkey and adjacent regions, Geophys. J. Int., 187, 1743-1758, doi:10.1111/j.1365-246X.2011.05235.x

Nicolas, A., and N.I. Christensen, 1987. Formation of anisotropy in upper mantle peridotites - A review, in Composition structure and dynamics of the lithosphere asthenosphere system, eds K. Fuchs and C. Froidevaux, Geodynamic Series AGU, Washington D.C., pp. 111-123.

Olive, J. L., S. Rondenay, and F. D. Pearce, 2011. Evidence for trench-normal flow beneath the Western Hellenic slab from shear-wave splitting analysis, Abstract DI41A-2067, 2011 Fall Meeting, AGU, San Francisco, Calif., 5-9 Dec.

Özeren, S.M., and W.E. Holt, 2010. The dynamics of the eastern Mediterranean and eastern Turkey, Geophys. J. Int., 183, 1165-1184, doi: 10.1111/j.1365-246X.2010.04819.x

Papazachos, B.C., V.G. Karakostas, C.B. Papazachos, and E.M. Scordilis, 2000. The geometry of the Wadati-Benioff zone and lithospheric kinematics in the Hellenic arc, Tectonophysics, 319, 275-300.

Piromallo C., and A. Morelli, 2003. P wave tomography of the mantle under the AlpineMediterranean area. J. Geophys. Res., 108(B2), 2065.

Pourteau A., O. Candan, and R. Oberhänsli, 2010. High-pressure metasediments in central Turkey: Constraints on the Neotethyan closure history, Tectonics, 29, TC5004, doi:10.1029/2009TC002650.

Reilinger, R., et al., 2006. GPS constraints on continental deformation in the Africa-ArabiaEurasia continental collision zone and implications for the dynamics of plate interactions, J. geophys. Res., 111, B05411, doi:10.1029/2005JB004051. 
Ribe, N.M., 1992. On the relation between seismic anisotropy and finite strain, J. geophys. Res., 97, 8737-8747.

Richter, F., 1973. Dynamical models for sea floor spreading, Reviews of Geophysics and Space Physics, 11, 223-287.

Salaün, G., H.A. Pedersen, A. Paul, V. Farra, H. Karabulut, D. Hatzfeld, C. Papazachos, D.M. Childs, C. Péquegnat, and Simbaad Team, 2012. High-resolution surface wave tomography of the Aegean-Anatolia region: Constraints on upper mantle structure, Geophys. J. Int., 190, 406-420, doi: 10.1111/j.1365-246X.2012.05483.x.

Salaün, G., 2011. Structure et déformation du manteau supérieur de la région Egée-Anatolie par tomographie en ondes de Rayleigh, $\mathrm{PhD}$ thesis, University of Grenoble.

Sandvol, E., N. Turkelli, E. Zor, R. Gok, T. Bekler, C. Burguz, D. Seber, and M. Barazangi, 2003. Shear wave splitting in a young continent-continent collision: An example from Eastern Turkey, Geophys. Res. Lett., 30, 24, 8041, doi:10.1029/2003GL017390

Savage, M. K., 1999. Seismic anisotropy and mantle deformation: What have we learned from shear wave splitting? Rev. Geophys., 37, 65-106, doi:10.1029/98RG02075.

Sengör, A.M.C., S. Ozeren, T. Genc, and E. Zor, 2003. East Anatolian high plateau as a mantle-supported, north-south shortened domal structure, Geophys. Res. Lett., 30, 24, 8045.

Silver, P. G., 1996. Seismic anisotropy beneath the continents: Probing the depths of geology, Annu. Rev. Earth Planet. Sci., 24, 385 - 432, doi:10.1146/annurev.earth.24.1.385.

Silver, P. G., and W. W. Chan, 1991. Shear wave splitting and subcontinental mantle deformation, J. geophys. Res. 96, B10, 16,429-16,454.

Silver, P. G., and M. K. Savage, 1994. The interpretation of shear-wave splitting parameters in the presence of two anisotropic layers, Geophys. J. Int., 119, 949-963.

Silver P. G., and W. E. Holt, 2002. The mantle flow field beneath Western North America, Science, 295, 1054-1057.

Sodoudi, F., et al., 2006. Lithospheric structure of the Aegean obtained from P and S receiver functions, J. geophys. Res., 111, B12307, doi:10.1029/2005JB003932.

Turcotte, D.L., and E.R. Oxburgh, 1967. Finite-amplitude convective cells and continental drift, J. Fluid Mechanics, 28, 29-42.

Wüstefeld, A., and G. Bokelmann, 2007, Null detection in shear-wave splitting measurements, Bull. Seis. Soc. Am., 97, 1204-1211, doi:10.1785/0120060190

Wüstefeld, A., G. Bokelmann, C. Zaroli, and G. Barruol, 2008. SplitLab: A shear-wave splitting environment in Matlab, Computers \& Geosciences, 34, 515-528.

Wüstefeld, A., G.H.R. Bokelmann, G. Barruol, and J. P. Montagner, 2009. Identifying global seismic anisotropy patterns by correlating shear-wave splitting and surface-wave data, Phys. Earth Planet. Int., 176, 198-212. 


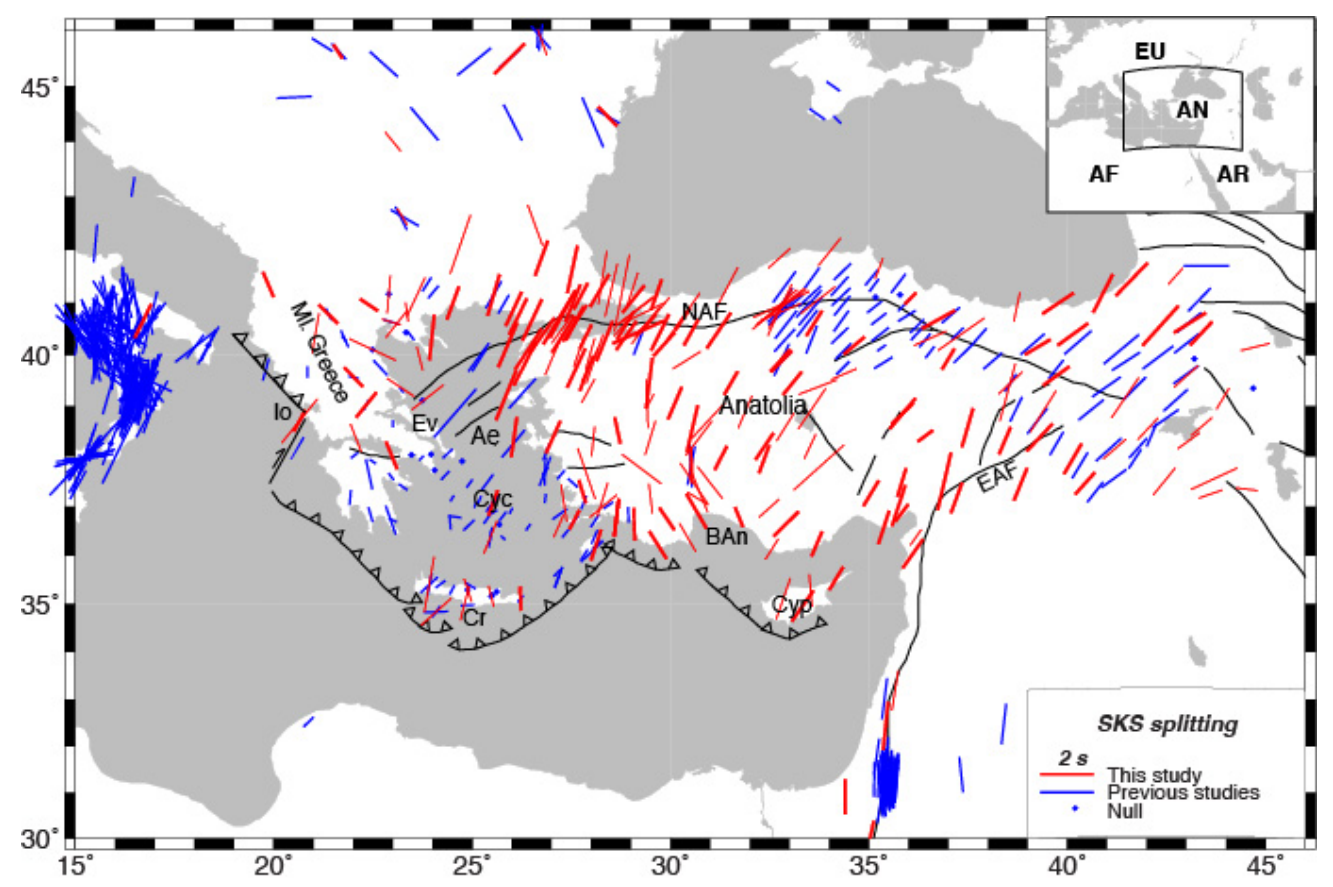

Figure 1 

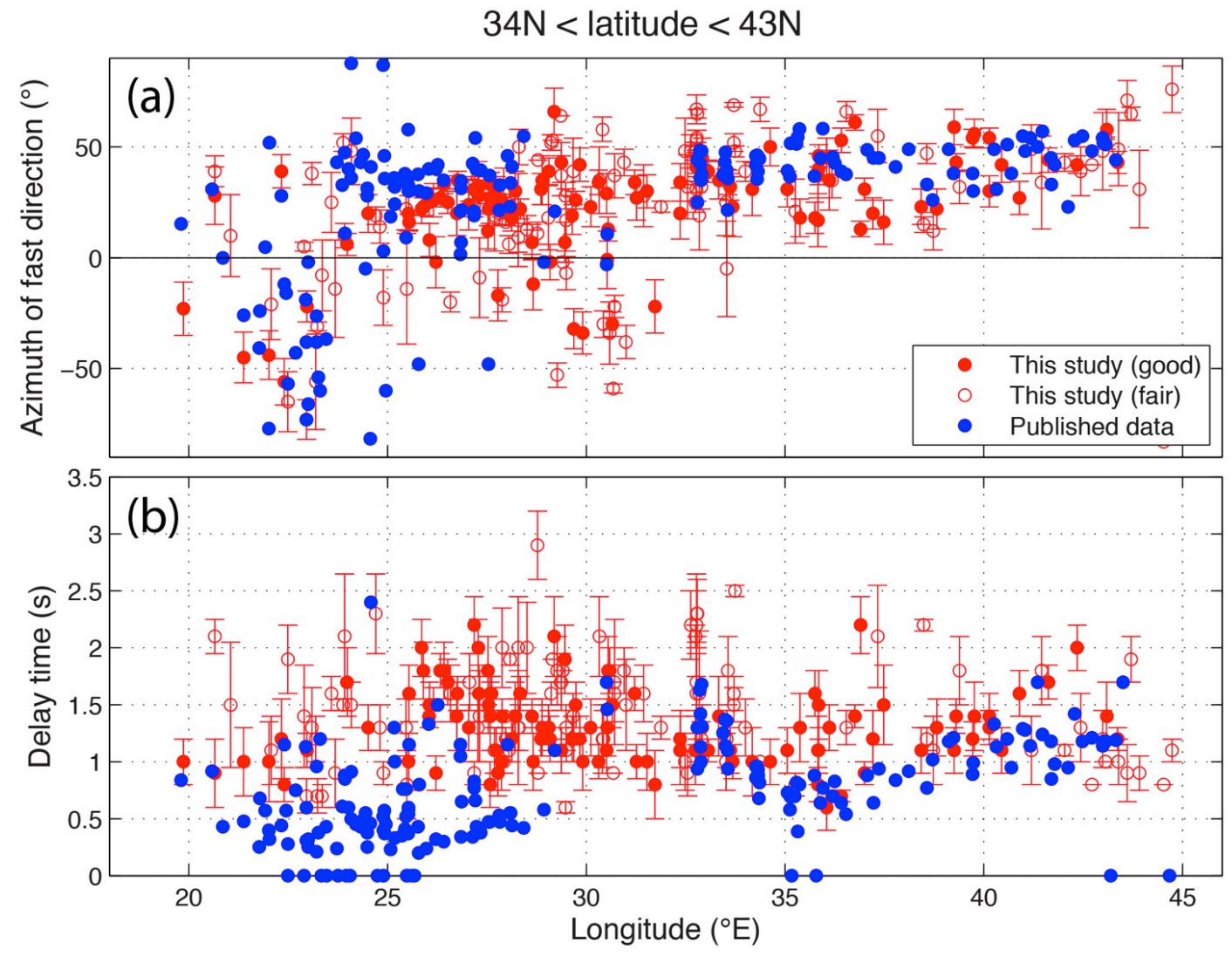

Figure 2 


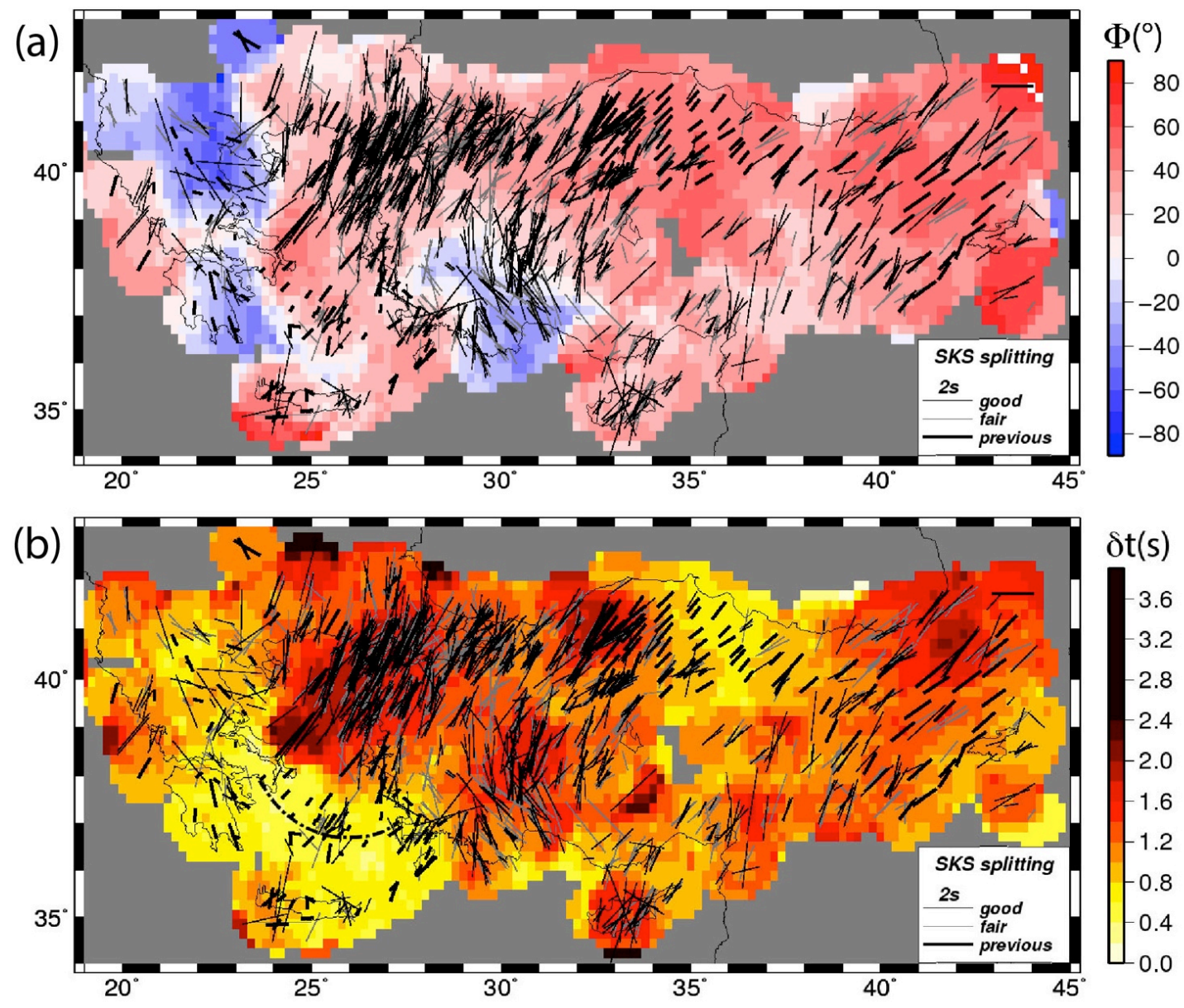

Figure 3 

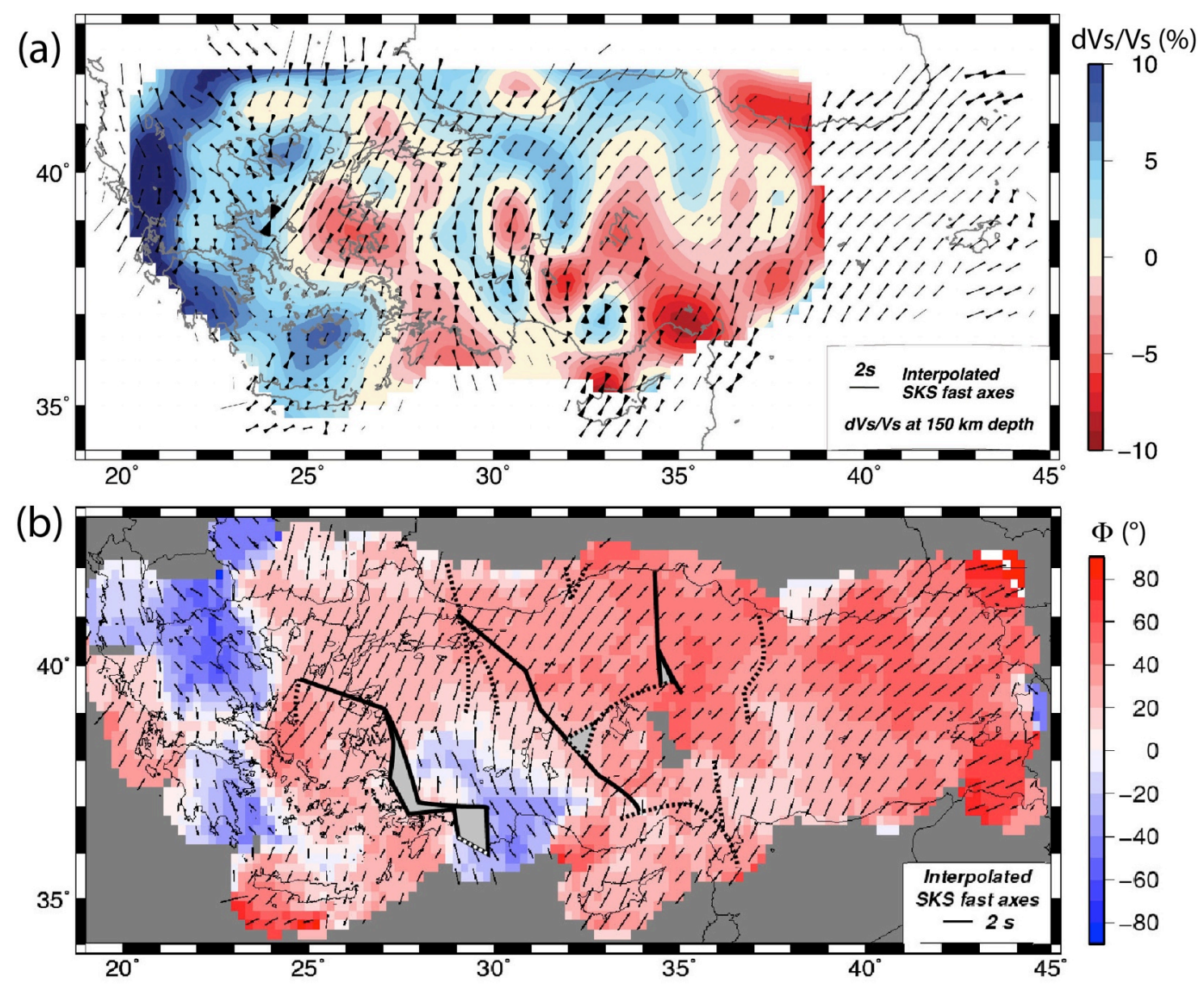

Figure 4 
Max. Horizontal Extension, Depth 170km [TX2007 \& V1 visc]

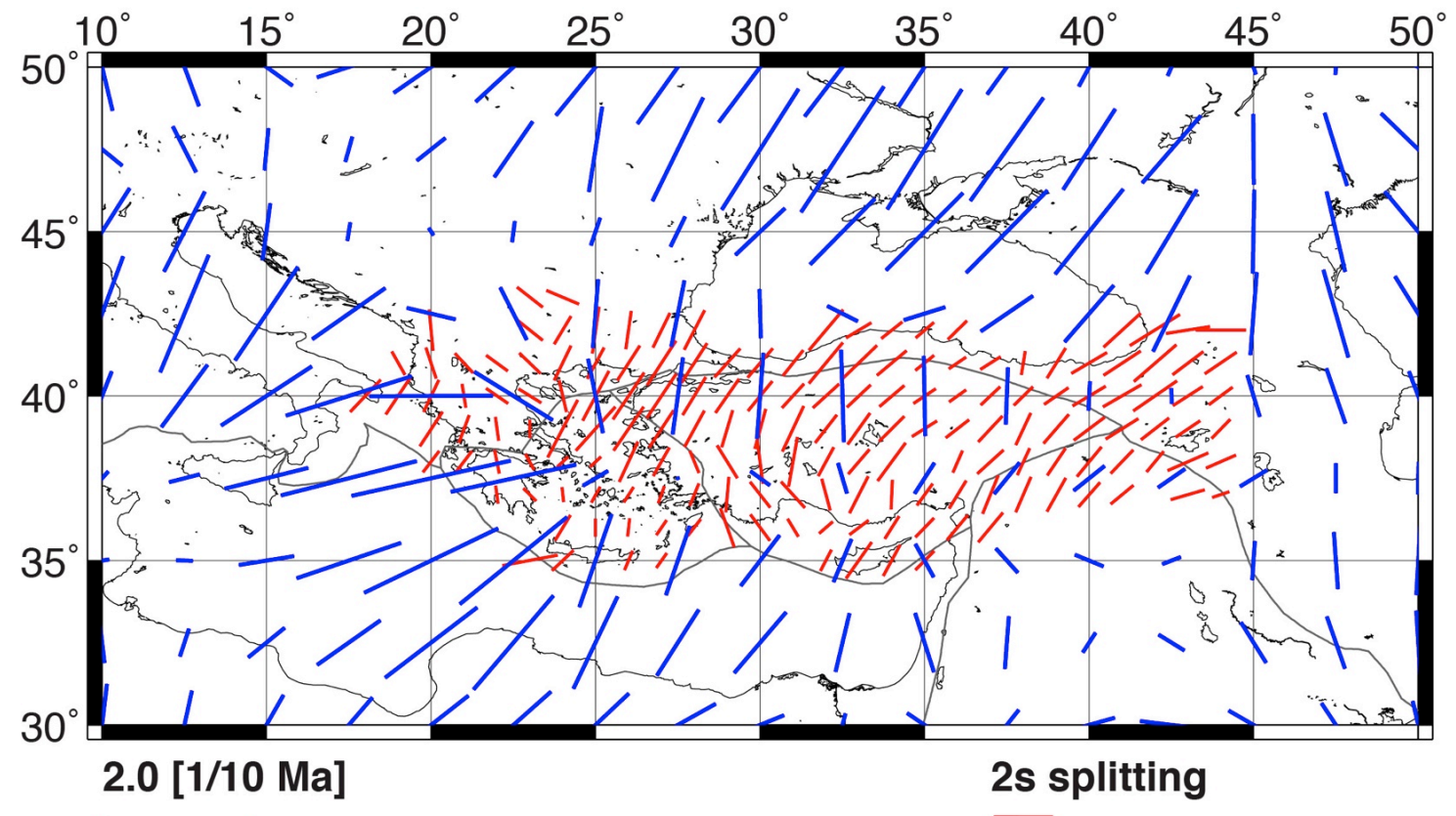

Figure 5 
Table 1: Results of splitting measurements averaged by station. Stations with the most reliable estimates of the mean $\Phi$ and $\delta \mathrm{t}$ (number of good or fair non-null measurements $>3$; standard deviation on $\delta \mathrm{t}<0.8 \mathrm{~s}$; standard deviation on $\Phi<25^{\circ}$ ) appear in the top part of the table (112 stations); they are shown as thick red line segments in Figure 1. Stations with less reliable average splitting parameters are in the lower part of the table (104 stations); they are shown as thin red line segments in Figure 1.

\begin{tabular}{|c|c|c|c|c|c|c|c|c|c|}
\hline Station code & $\begin{array}{l}\text { Latitude } \\
\left({ }^{\circ} \mathrm{N}\right)\end{array}$ & $\begin{array}{l}\text { Longitude } \\
\left({ }^{\circ} \mathrm{E}\right)\end{array}$ & Mean $\Phi\left(\left(^{\circ}\right)\right.$ & Mean $\delta t ~(s)$ & Std on $\Phi\left(\left(^{\circ}\right)\right.$ & Std on $\delta t(s)$ & $\begin{array}{c}\text { Total } \mathrm{nr} \text { of } \\
\text { measurements }\end{array}$ & $\begin{array}{c}\mathrm{Nr} \text { of good or fair non } \\
\text { null measurements }\end{array}$ & $\begin{array}{c}\mathrm{Nr} \text { of good or fair } \\
\text { null measurements }\end{array}$ \\
\hline ADVT & 40.4332 & 29.7383 & 26 & 1.5 & 8 & 0.4 & 41 & 23 & 7 \\
\hline AFSR & 39.4470 & 33.0710 & 39 & 1.1 & 10 & 0.2 & 39 & 20 & 3 \\
\hline AGG & 39.0222 & 22.3303 & 39 & 1.2 & 15 & 0.7 & 62 & 15 & 29 \\
\hline ALN & 40.8850 & 26.0460 & 25 & 1.4 & 13 & 0.2 & 28 & 19 & 2 \\
\hline ALT & 39.0552 & 30.1103 & 23 & 1.3 & 18 & 0.5 & 65 & 24 & 15 \\
\hline ANTB & 36.8998 & 30.6538 & -30 & 1.5 & 11 & 0.4 & 70 & 20 & 13 \\
\hline ANTO & 39.8689 & 32.7936 & 45 & 1.1 & 14 & 0.2 & 33 & 15 & 5 \\
\hline APE & 37.0689 & 25.5306 & 20 & 1.0 & 16 & 0.5 & 127 & 32 & 47 \\
\hline ARG & 36.2160 & 28.1260 & 18 & 1.2 & 12 & 0.4 & 9 & 4 & 2 \\
\hline ARMT & 40.5658 & 28.8613 & 31 & 1.2 & 14 & 0.3 & 32 & 13 & 2 \\
\hline BALB & 39.6400 & 27.8800 & 21 & 1.4 & 12 & 0.3 & 102 & 56 & 7 \\
\hline BALY & 39.7403 & 27.6195 & 25 & 1.6 & 7 & 0.3 & 15 & 10 & 1 \\
\hline BAYT & 40.3935 & 40.1410 & 54 & 1.4 & 9 & 0.4 & 28 & 17 & 0 \\
\hline BCA & 41.4450 & 41.6223 & 44 & 1.7 & 11 & 0.3 & 33 & 11 & 3 \\
\hline BEL & 37.9708 & 31.2642 & 27 & 1.0 & 20 & 0.3 & 80 & 25 & 26 \\
\hline $\mathrm{BLCB}$ & 38.3853 & 27.0420 & 24 & 1.3 & 23 & 0.4 & 126 & 48 & 31 \\
\hline BNGB & 38.8520 & 35.8470 & 46 & 1.1 & 10 & 0.4 & 23 & 9 & 0 \\
\hline BNN & 38.8522 & 35.8472 & 40 & 1.5 & 14 & 0.6 & 40 & 7 & 22 \\
\hline BZS & 45.6167 & 21.6167 & -33 & 0.6 & 26 & 0.2 & 19 & 6 & 3 \\
\hline CANT & 40.6062 & 33.6197 & 32 & 1.1 & 12 & 0.4 & 67 & 27 & 9 \\
\hline CAVI & 40.2019 & 29.8376 & 42 & 1.2 & 15 & 0.4 & 70 & 25 & 10 \\
\hline CEYT & 37.0107 & 35.7478 & 18 & 1.6 & 14 & 0.4 & 47 & 10 & 9 \\
\hline $\mathrm{CHOS}$ & 38.3868 & 26.0550 & 8 & 1.5 & 15 & 0.4 & 77 & 12 & 28 \\
\hline CORM & 40.1785 & 34.6302 & 50 & 1.0 & 17 & 0.4 & 69 & 28 & 8 \\
\hline CRLT & 41.1290 & 27.7360 & 28 & 1.1 & 17 & 0.4 & 26 & 10 & 2 \\
\hline CSS & 34.9611 & 33.3310 & 35 & 1.4 & 17 & 0.7 & 106 & 34 & 25 \\
\hline DALT & 36.7692 & 28.6372 & 7 & 1.4 & 16 & 0.2 & 32 & 4 & 11 \\
\hline DALY & 36.7692 & 28.6372 & 7 & 1.4 & 11 & 0.3 & 15 & 4 & 4 \\
\hline DARE & 38.5712 & 37.4832 & 16 & 1.5 & 20 & 0.7 & 30 & 6 & 6 \\
\hline DAT & 36.7290 & 27.5778 & 27 & 0.8 & 23 & 0.4 & 108 & 21 & 38 \\
\hline DIGO & 40.4088 & 43.3712 & 43 & 1.2 & 10 & 0.2 & 6 & 4 & 0 \\
\hline DYBB & 37.9537 & 40.1393 & 30 & 1.3 & 14 & 0.3 & 34 & 21 & 0 \\
\hline EDC & 40.3468 & 27.8633 & 26 & 1.0 & 15 & 0.5 & 24 & 7 & 0 \\
\hline EDRB & 41.8470 & 26.7437 & 20 & 1.4 & 20 & 0.6 & 121 & 35 & 36 \\
\hline ELL & 36.7483 & 29.9085 & -34 & 1.0 & 19 & 0.5 & 107 & 34 & 20 \\
\hline ENEZ & 40.7362 & 26.1530 & 26 & 1.5 & 15 & 0.3 & 85 & 40 & 8 \\
\hline ERBA & 40.6813 & 36.7547 & 61 & 1.4 & 7 & 0.2 & 8 & 4 & 0 \\
\hline EREN & 35.5292 & 34.1742 & 31 & 1.0 & 24 & 0.6 & 135 & 29 & 68 \\
\hline ERIK & 40.6710 & 26.5130 & 25 & 1.7 & 10 & 0.4 & 33 & 27 & 1 \\
\hline ERMK & 36.6417 & 32.9128 & 45 & 1.3 & 18 & 0.4 & 22 & 7 & 0 \\
\hline ERZN & 39.5870 & 39.7220 & 54 & 1.2 & 8 & 0.3 & 21 & 14 & 0 \\
\hline EZN & 39.8267 & 26.3258 & 27 & 1.8 & 8 & 0.3 & 59 & 34 & 3 \\
\hline FETY & 36.6353 & 29.0835 & -2 & 1.2 & 16 & 0.4 & 58 & 8 & 25 \\
\hline FNA & 40.7838 & 21.3762 & -45 & 1.0 & 23 & 0.6 & 60 & 17 & 30 \\
\hline GADA & 40.1908 & 25.8987 & 23 & 1.8 & 8 & 0.5 & 76 & 46 & 12 \\
\hline GAZ & 37.1722 & 37.2113 & 20 & 1.2 & 14 & 0.5 & 47 & 14 & 20 \\
\hline GEMT & 40.4350 & 29.1890 & 66 & 2.1 & 21 & 0.7 & 62 & 5 & 15 \\
\hline GRG & 40.9567 & 22.4014 & -56 & 0.8 & 21 & 0.3 & 48 & 14 & 14 \\
\hline GULT & 40.4322 & 30.5153 & 29 & 1.1 & 18 & 0.4 & 111 & 53 & 14 \\
\hline $\mathrm{HRFI}$ & 30.0363 & 35.0370 & 12 & 1.2 & 16 & 0.4 & 13 & 7 & 0 \\
\hline IKL & 36.2387 & 33.6852 & 23 & 1.0 & 27 & 0.3 & 104 & 22 & 38 \\
\hline ISK & 41.0657 & 29.0592 & 39 & 1.3 & 12 & 0.3 & 105 & 60 & 14 \\
\hline ISP & 37.8227 & 30.5222 & -1 & 1.3 & 26 & 0.5 & 97 & 24 & 34 \\
\hline KARA & 37.2607 & 35.0547 & 31 & 1.1 & 16 & 0.4 & 61 & 12 & 39 \\
\hline
\end{tabular}




\begin{tabular}{|c|c|c|c|c|c|c|c|c|c|}
\hline KARS & 40.6152 & 43.0937 & 58 & 1.4 & 18 & 0.6 & 31 & 4 & 17 \\
\hline KAS & 36.2132 & 29.6836 & -32 & 1.2 & 18 & 0.4 & 45 & 17 & 16 \\
\hline KAVA & 40.9941 & 24.5119 & 20 & 1.3 & 17 & 0.4 & 32 & 13 & 10 \\
\hline KCTX & 40.2630 & 28.3350 & 22 & 1.6 & 9 & 0.3 & 44 & 27 & 7 \\
\hline KELT & 40.1495 & 39.2557 & 59 & 1.1 & 16 & 0.4 & 10 & 6 & 0 \\
\hline KIV & 43.9553 & 42.6863 & 35 & 1.0 & 24 & 0.4 & 16 & 5 & 6 \\
\hline KMRS & 37.5053 & 36.9000 & 13 & 2.2 & 7 & 0.5 & 55 & 5 & 18 \\
\hline KONT & 37.9453 & 32.3605 & 20 & 1.1 & 23 & 0.6 & 78 & 28 & 18 \\
\hline KOZT & 37.4805 & 35.8268 & 17 & 1.1 & 24 & 0.6 & 47 & 7 & 16 \\
\hline KRBG & 40.3930 & 27.2980 & 32 & 1.6 & 15 & 0.5 & 22 & 11 & 4 \\
\hline KRTS & 36.5732 & 35.3750 & 18 & 1.3 & 17 & 0.6 & 18 & 7 & 6 \\
\hline KTUT & 40.9870 & 39.7667 & 56 & 1.4 & 13 & 0.6 & 27 & 17 & 4 \\
\hline KULA & 38.5145 & 28.6607 & -12 & 1.0 & 23 & 0.5 & 77 & 9 & 36 \\
\hline KVT & 41.0807 & 36.0463 & 45 & 0.6 & 18 & 0.4 & 51 & 11 & 16 \\
\hline KZIT & 30.9063 & 34.3972 & 0 & 1.3 & 16 & 0.4 & 18 & 8 & 2 \\
\hline LADK & 38.2000 & 32.3648 & 34 & 1.2 & 17 & 0.5 & 33 & 11 & 4 \\
\hline LAP & 40.3727 & 26.7602 & 35 & 1.6 & 8 & 0.3 & 31 & 24 & 1 \\
\hline LKD & 38.7075 & 20.6505 & 28 & 0.9 & 26 & 0.6 & 29 & 10 & 8 \\
\hline LOD & 39.8893 & 32.7640 & 41 & 1.1 & 13 & 0.3 & 83 & 41 & 12 \\
\hline LTK & 38.0228 & 22.9673 & -22 & 1.1 & 14 & 0.3 & 19 & 6 & 7 \\
\hline MALT & 38.3134 & 38.4273 & 23 & 1.1 & 16 & 0.4 & 51 & 13 & 9 \\
\hline MAN & 36.7817 & 31.7247 & -22 & 0.8 & 24 & 0.6 & 55 & 6 & 45 \\
\hline MATE & 40.6490 & 16.7040 & 26 & 1.4 & 20 & 0.4 & 29 & 18 & 1 \\
\hline MAZI & 37.4603 & 40.4467 & 42 & 1.1 & 16 & 0.4 & 7 & 6 & 0 \\
\hline MDNY & 40.3706 & 28.8844 & 35 & 1.3 & 22 & 0.5 & 40 & 12 & 5 \\
\hline MDU & 40.4653 & 31.2145 & 34 & 1.6 & 11 & 0.3 & 21 & 11 & 0 \\
\hline MERS & 36.8677 & 35.8268 & 37 & 0.8 & 20 & 0.3 & 62 & 8 & 33 \\
\hline MFTX & 40.7867 & 27.2812 & 28 & 2.0 & 14 & 0.5 & 25 & 17 & 1 \\
\hline MLR & 45.4912 & 25.9456 & 45 & 1.6 & 11 & 0.5 & 13 & 10 & 0 \\
\hline MLSB & 37.2953 & 27.7765 & -17 & 0.9 & 23 & 0.4 & 50 & 5 & 24 \\
\hline MMLI & 32.4378 & 35.4217 & 6 & 1.8 & 6 & 0.6 & 14 & 4 & 1 \\
\hline MRMT & 40.6060 & 27.5840 & 33 & 1.6 & 11 & 0.3 & 20 & 12 & 0 \\
\hline MRMX & 40.6058 & 27.5837 & 27 & 1.4 & 14 & 0.6 & 23 & 11 & 4 \\
\hline OUR & 40.3344 & 23.9819 & 6 & 1.7 & 10 & 0.6 & 26 & 9 & 8 \\
\hline PHSR & 41.6310 & 27.5240 & 12 & 1.8 & 16 & 0.6 & 26 & 10 & 4 \\
\hline PZAR & 41.1780 & 40.8988 & 27 & 1.6 & 15 & 0.4 & 13 & 4 & 2 \\
\hline RDO & 41.1460 & 25.5380 & 16 & 1.6 & 7 & 0.5 & 9 & 5 & 3 \\
\hline RKY & 40.6875 & 27.1777 & 31 & 2.2 & 11 & 0.5 & 78 & 52 & 5 \\
\hline SARI & 38.4072 & 36.4182 & 53 & 0.7 & 11 & 0.1 & 19 & 6 & 6 \\
\hline SENK & 40.5615 & 42.3507 & 42 & 2.0 & 8 & 0.4 & 15 & 10 & 0 \\
\hline SHUT & 38.5530 & 30.5510 & 13 & 1.8 & 11 & 0.6 & 73 & 37 & 8 \\
\hline SIGR & 39.2114 & 25.8553 & 22 & 2.0 & 13 & 0.5 & 17 & 13 & 0 \\
\hline SILT & 41.1530 & 29.6430 & 19 & 1.2 & 17 & 0.4 & 73 & 17 & 16 \\
\hline SLVT & 41.2300 & 28.2100 & 30 & 1.4 & 18 & 0.6 & 62 & 13 & 8 \\
\hline SPNC & 40.6860 & 30.3080 & 34 & 1.0 & 11 & 0.3 & 31 & 16 & 0 \\
\hline SVRC & 38.3775 & 39.3060 & 43 & 1.4 & 8 & 0.3 & 21 & 5 & 5 \\
\hline SVRH & 39.4469 & 31.5230 & 30 & 1.0 & 15 & 0.5 & 50 & 17 & 13 \\
\hline SVSK & 39.9170 & 36.9980 & 31 & 0.9 & 10 & 0.2 & 57 & 22 & 9 \\
\hline THL & 39.5647 & 22.0145 & -44 & 1.0 & 22 & 0.7 & 62 & 8 & 32 \\
\hline TIR & 41.3472 & 19.8631 & -23 & 1.0 & 24 & 0.4 & 47 & 20 & 24 \\
\hline TIRR & 44.4581 & 28.4128 & -44 & 1.0 & 23 & 0.3 & 26 & 12 & 4 \\
\hline TKR & 40.9902 & 27.5357 & 22 & 1.5 & 15 & 0.5 & 22 & 14 & 0 \\
\hline TROY & 40.1096 & 26.4185 & 33 & 1.8 & 8 & 0.5 & 9 & 7 & 1 \\
\hline TVSB & 39.4500 & 29.4620 & 7 & 1.9 & 18 & 0.6 & 40 & 11 & 2 \\
\hline URFA & 37.4410 & 38.8213 & 22 & 1.3 & 18 & 0.5 & 76 & 26 & 9 \\
\hline YAYL & 36.0343 & 36.1070 & 35 & 1.3 & 27 & 0.4 & 15 & 4 & 1 \\
\hline YLVX & 40.5667 & 29.3728 & 43 & 1.1 & 18 & 0.4 & 48 & 16 & 9 \\
\hline ZKR & 35.1147 & 26.2170 & -2 & 0.9 & 23 & 0.3 & 50 & 8 & 23 \\
\hline AHLR & 40.8867 & 32.7735 & 31 & 1.7 & 11 & 0.5 & 7 & 2 & 3 \\
\hline ALTB & 28.7400 & 41.0900 & 43 & 1.1 & 5 & 0.4 & 5 & 3 & 0 \\
\hline AOS & 39.1703 & 23.8800 & 52 & 1.5 & 8 & 0.1 & 7 & 3 & 1 \\
\hline AYDN & 37.6608 & 27.8792 & -19 & 2.0 & 11 & 0.7 & 15 & 2 & 4 \\
\hline BCK & 37.4610 & 30.5877 & -34 & 1.8 & 28 & 0.4 & 24 & 5 & 10 \\
\hline BGKT & 41.1810 & 28.7730 & 11 & 2.9 & 10 & 0.6 & 22 & 1 & 3 \\
\hline BLKV & 40.8613 & 32.7517 & 25 & 2.1 & 9 & 0.2 & 2 & 1 & 0 \\
\hline BODT & 37.0622 & 27.3103 & -9 & 1.4 & 36 & 0.8 & 116 & 10 & 55 \\
\hline BOLV & 38.7138 & 30.9502 & 43 & 1.8 & 12 & 0.4 & 14 & 3 & 0 \\
\hline BOZX & 40.5340 & 28.7820 & 44 & 0.9 & 0 & 0.0 & 3 & 1 & 2 \\
\hline BUYB & 40.8520 & 29.1180 & 52 & 1.6 & 7 & 0.2 & 9 & 3 & 3 \\
\hline BYDR & 40.8237 & 32.7738 & 67 & 1.6 & 13 & 0.9 & 3 & 3 & 0 \\
\hline BZK & 41.9600 & 34.0035 & 39 & 1.3 & 9 & 0.5 & 44 & 1 & 38 \\
\hline CANB & 40.0167 & 27.0625 & 23 & 1.7 & 5 & 0.5 & 7 & 3 & 1 \\
\hline CDAG & 39.6237 & 34.3718 & 67 & 1.0 & 11 & 0.0 & 6 & 2 & 1 \\
\hline
\end{tabular}




\begin{tabular}{|c|c|c|c|c|c|c|c|c|c|}
\hline CETI & 37.0030 & 28.3070 & 50 & 1.3 & 16 & 0.4 & 11 & 1 & 3 \\
\hline $\mathrm{CHBY}$ & 38.5823 & 32.8902 & 32 & 1.2 & 20 & 0.3 & 7 & 3 & 0 \\
\hline CLDR & 39.1440 & 43.9172 & 31 & 0.9 & 35 & 0.3 & 28 & 8 & 13 \\
\hline $\mathrm{CMHB}$ & 40.0120 & 27.9700 & 16 & 1.2 & 3 & 0.2 & 3 & 1 & 0 \\
\hline CMLK & 40.9650 & 32.7937 & 65 & 2.3 & 4 & 0.6 & 5 & 2 & 2 \\
\hline CRAR & 44.0033 & 23.0008 & -39 & 0.9 & 17 & 0.3 & 15 & 1 & 1 \\
\hline CTKS & 41.2364 & 28.5066 & 13 & 2.0 & 12 & 0.8 & 19 & 1 & 0 \\
\hline CTYL & 41.4750 & 28.2891 & 9 & 2.0 & 13 & 0.9 & 10 & 2 & 1 \\
\hline CUKT & 37.2473 & 43.6077 & 71 & 0.9 & 18 & 0.5 & 29 & 2 & 12 \\
\hline DIKM & 41.6497 & 35.2578 & 21 & 0.8 & 29 & 0.2 & 34 & 1 & 23 \\
\hline E08 & 39.8969 & 30.4047 & 58 & 1.2 & 11 & 0.6 & 7 & 3 & 1 \\
\hline E13 & 38.3603 & 30.7144 & 37 & 1.6 & 20 & 0.5 & 3 & 3 & 0 \\
\hline E17 & 37.3208 & 30.7133 & -22 & 1.7 & 10 & 1.1 & 8 & 3 & 1 \\
\hline E18 & 37.1631 & 30.6811 & -59 & 0.9 & 4 & 0.0 & 5 & 2 & 2 \\
\hline E23 & 36.3669 & 30.4300 & -30 & 1.2 & 12 & 0.5 & 8 & 3 & 0 \\
\hline EPOS & 41.5035 & 42.7279 & 42 & 0.8 & 0 & 0.0 & 3 & 1 & 2 \\
\hline ESPY & 40.9167 & 38.7273 & 12 & 1.1 & 17 & 0.6 & 7 & 3 & 1 \\
\hline GDZ & 39.0888 & 29.4812 & 28 & 0.6 & 12 & 0.1 & 10 & 2 & 4 \\
\hline GEDZ & 39.0445 & 29.4105 & -2 & 1.8 & 0 & 0.0 & 3 & 1 & 0 \\
\hline GEVA & 38.3122 & 43.0587 & 54 & 1.0 & 1 & 0.0 & 2 & 2 & 0 \\
\hline GLHS & 37.1560 & 29.4983 & -7 & 1.1 & 15 & 0.2 & 5 & 1 & 2 \\
\hline GNI & 40.1495 & 44.7413 & 76 & 1.1 & 21 & 0.2 & 18 & 1 & 11 \\
\hline GONE & 40.0470 & 27.6860 & 19 & 1.1 & 32 & 0.4 & 20 & 5 & 8 \\
\hline GURO & 38.5509 & 42.0322 & 43 & 1.1 & 8 & 0.1 & 8 & 1 & 4 \\
\hline GVD & 34.8392 & 24.0873 & 48 & 1.5 & 30 & 0.4 & 16 & 2 & 9 \\
\hline GYTE & 40.8123 & 29.3485 & 64 & 1.7 & 0 & 0.0 & 3 & 1 & 2 \\
\hline HAKT & 37.5578 & 43.7072 & 65 & 1.9 & 6 & 0.4 & 5 & 3 & 2 \\
\hline HDMB & 36.9640 & 32.4860 & 48 & 1.0 & 30 & 0.5 & 65 & 3 & 43 \\
\hline $\mathrm{HNZ}$ & 37.7495 & 29.2696 & -53 & 1.8 & 11 & 0.6 & 5 & 2 & 0 \\
\hline HORT & 40.5978 & 23.0996 & 38 & 1.3 & 10 & 0.7 & 18 & 3 & 9 \\
\hline HRTX & 40.8217 & 29.6680 & 39 & 1.4 & 30 & 0.4 & 49 & 25 & 4 \\
\hline IDI & 35.2880 & 24.8900 & -18 & 0.9 & 25 & 0.2 & 17 & 1 & 12 \\
\hline ILGA & 41.0522 & 33.7165 & 52 & 1.6 & 8 & 0.3 & 8 & 3 & 0 \\
\hline ILIC & 39.4520 & 38.5680 & 47 & 1.2 & 9 & 0.2 & 11 & 2 & 3 \\
\hline INL & 36.1289 & 32.5501 & 32 & 0.9 & 29 & 0.4 & 77 & 27 & 33 \\
\hline $\mathrm{JMB}$ & 42.4667 & 26.5833 & -20 & 1.6 & 9 & 0.5 & 5 & 3 & 1 \\
\hline KAMT & 39.3692 & 33.7127 & 69 & 1.5 & 2 & 0.3 & 7 & 1 & 2 \\
\hline KARN & 35.4019 & 23.9174 & 10 & 2.1 & 11 & 1.1 & 14 & 4 & 5 \\
\hline KDZE & 41.3132 & 31.4430 & 28 & 1.6 & 28 & 0.5 & 22 & 12 & 4 \\
\hline KEMA & 39.2688 & 38.4932 & 15 & 2.2 & 7 & 0.1 & 11 & 3 & 1 \\
\hline KHAL & 38.3703 & 29.4917 & 17 & 1.3 & 28 & 0.4 & 15 & 6 & 0 \\
\hline KIZT & 38.8800 & 31.8800 & 23 & 1.3 & 5 & 0.2 & 7 & 2 & 3 \\
\hline KLYT & 41.2530 & 29.0420 & 18 & 1.3 & 29 & 0.4 & 35 & 9 & 15 \\
\hline KNT & 41.1619 & 22.8981 & 5 & 1.4 & 4 & 0.9 & 9 & 2 & 5 \\
\hline KRNZ & 40.9093 & 32.7847 & 54 & 2.3 & 7 & 0.4 & 4 & 2 & 1 \\
\hline KSDI & 33.1920 & 35.6590 & 9 & 1.5 & 0 & 0.2 & 5 & 3 & 2 \\
\hline KURC & 41.8456 & 32.7430 & 48 & 1.1 & 8 & 0.6 & 4 & 2 & 0 \\
\hline LAST & 35.1611 & 25.4786 & -14 & 0.8 & 50 & 0.6 & 64 & 6 & 34 \\
\hline LEF & 35.1118 & 32.8433 & 19 & 1.6 & 31 & 1.1 & 103 & 13 & 55 \\
\hline LFK & 35.2832 & 33.5337 & -5 & 1.2 & 43 & 0.5 & 54 & 9 & 35 \\
\hline LIT & 40.1003 & 22.4893 & -65 & 1.9 & 27 & 0.6 & 13 & 2 & 1 \\
\hline LKD & 38.7075 & 20.6505 & 39 & 2.1 & 14 & 0.3 & 3 & 1 & 0 \\
\hline NEST & 40.4147 & 21.0489 & 10 & 1.5 & 37 & 1.1 & 19 & 7 & 10 \\
\hline NIS1 & 36.6023 & 27.1782 & 24 & 0.9 & 11 & 0.2 & 14 & 2 & 9 \\
\hline PAIG & 39.9272 & 23.6797 & -14 & 0.9 & 44 & 0.6 & 65 & 23 & 15 \\
\hline PASA & 40.8693 & 32.6240 & 48 & 2.2 & 15 & 0.6 & 5 & 3 & 1 \\
\hline PLD & 42.1048 & 24.7032 & 19 & 2.3 & 8 & 0.7 & 5 & 1 & 2 \\
\hline PTK & 38.8923 & 39.3923 & 32 & 1.8 & 15 & 0.6 & 20 & 2 & 6 \\
\hline RSDY & 40.3972 & 37.3273 & 55 & 2.1 & 24 & 0.9 & 26 & 1 & 7 \\
\hline SANT & 36.3710 & 25.4590 & 22 & 1.3 & 19 & 0.5 & 24 & 3 & 10 \\
\hline SAUV & 40.7402 & 30.3272 & 35 & 2.1 & 30 & 0.7 & 9 & 1 & 0 \\
\hline SEDF & 40.8497 & 29.1442 & 53 & 1.9 & 0 & 0.0 & 4 & 1 & 3 \\
\hline SEMD & 37.3473 & 44.5208 & -83 & 0.8 & 0 & 0.0 & 2 & 1 & 1 \\
\hline SERE & 38.9463 & 33.5640 & 34 & 1.8 & 11 & 0.6 & 9 & 3 & 0 \\
\hline SIRT & 37.5010 & 42.4392 & 39 & 1.3 & 22 & 0.6 & 7 & 2 & 4 \\
\hline SIVA & 35.0175 & 24.8100 & 14 & 1.3 & 15 & 0.4 & 20 & 1 & 9 \\
\hline $\mathrm{SOH}$ & 40.8206 & 23.3556 & -8 & 0.7 & 32 & 0.2 & 21 & 3 & 8 \\
\hline SRS & 41.1086 & 23.5846 & 25 & 1.6 & 27 & 0.3 & 13 & 3 & 5 \\
\hline SULT & 38.1988 & 33.5157 & 25 & 1.0 & 30 & 0.5 & 49 & 6 & 23 \\
\hline SUTC & 37.4755 & 30.9975 & -38 & 1.5 & 15 & 0.8 & 16 & 9 & 2 \\
\hline SVAN & 38.1512 & 41.1985 & 49 & 1.1 & 22 & 0.6 & 15 & 2 & 2 \\
\hline TAHT & 36.3760 & 36.1850 & 35 & 0.7 & 16 & 0.1 & 5 & 1 & 2 \\
\hline THE & 40.6319 & 22.9628 & -73 & 0.7 & 18 & 0.3 & 17 & 3 & 1 \\
\hline
\end{tabular}




\begin{tabular}{|c|c|c|c|c|c|c|c|c|c|}
\hline TKMK & 40.9298 & 32.7730 & 53 & 2.2 & 9 & 0.9 & 7 & 5 & 1 \\
\hline TOKT & 40.3203 & 36.5448 & 66 & 1.3 & 9 & 0.3 & 15 & 1 & 2 \\
\hline TRIZ & 38.3700 & 22.0700 & -21 & 1.1 & 32 & 0.6 & 61 & 10 & 34 \\
\hline TRNX & 40.5000 & 27.2700 & 36 & 1.3 & 15 & 0.6 & 8 & 1 & 0 \\
\hline VANB & 38.5950 & 43.3888 & 49 & 1.0 & 33 & 0.4 & 32 & 10 & 5 \\
\hline VRI & 45.8665 & 26.7277 & -19 & 1.4 & 28 & 0.7 & 9 & 4 & 2 \\
\hline VRTB & 39.1600 & 41.4560 & 34 & 1.8 & 42 & 0.6 & 15 & 9 & 0 \\
\hline VTS & 42.6180 & 23.2350 & -31 & 0.7 & 4 & 0.3 & 10 & 3 & 5 \\
\hline W04 & 39.9180 & 28.0860 & 19 & 1.9 & 3 & 0.1 & 3 & 2 & 0 \\
\hline W05 & 39.8030 & 27.9630 & 26 & 1.4 & 0 & 0.0 & 2 & 1 & 1 \\
\hline W07 & 39.2960 & 27.9210 & 29 & 1.0 & 23 & 0.2 & 4 & 3 & 1 \\
\hline W14 & 38.3010 & 28.0490 & 6 & 1.1 & 8 & 0.2 & 3 & 1 & 1 \\
\hline XOR & 39.3661 & 23.1919 & -56 & 1.2 & 43 & 0.4 & 41 & 4 & 31 \\
\hline YER & 37.1362 & 28.2858 & 17 & 1.3 & 42 & 1.0 & 86 & 10 & 53 \\
\hline YESY & 37.7800 & 33.7400 & 48 & 2.5 & 5 & 0.1 & 5 & 1 & 0 \\
\hline YLV & 40.5667 & 29.3728 & 37 & 1.7 & 18 & 0.5 & 6 & 1 & 1 \\
\hline
\end{tabular}



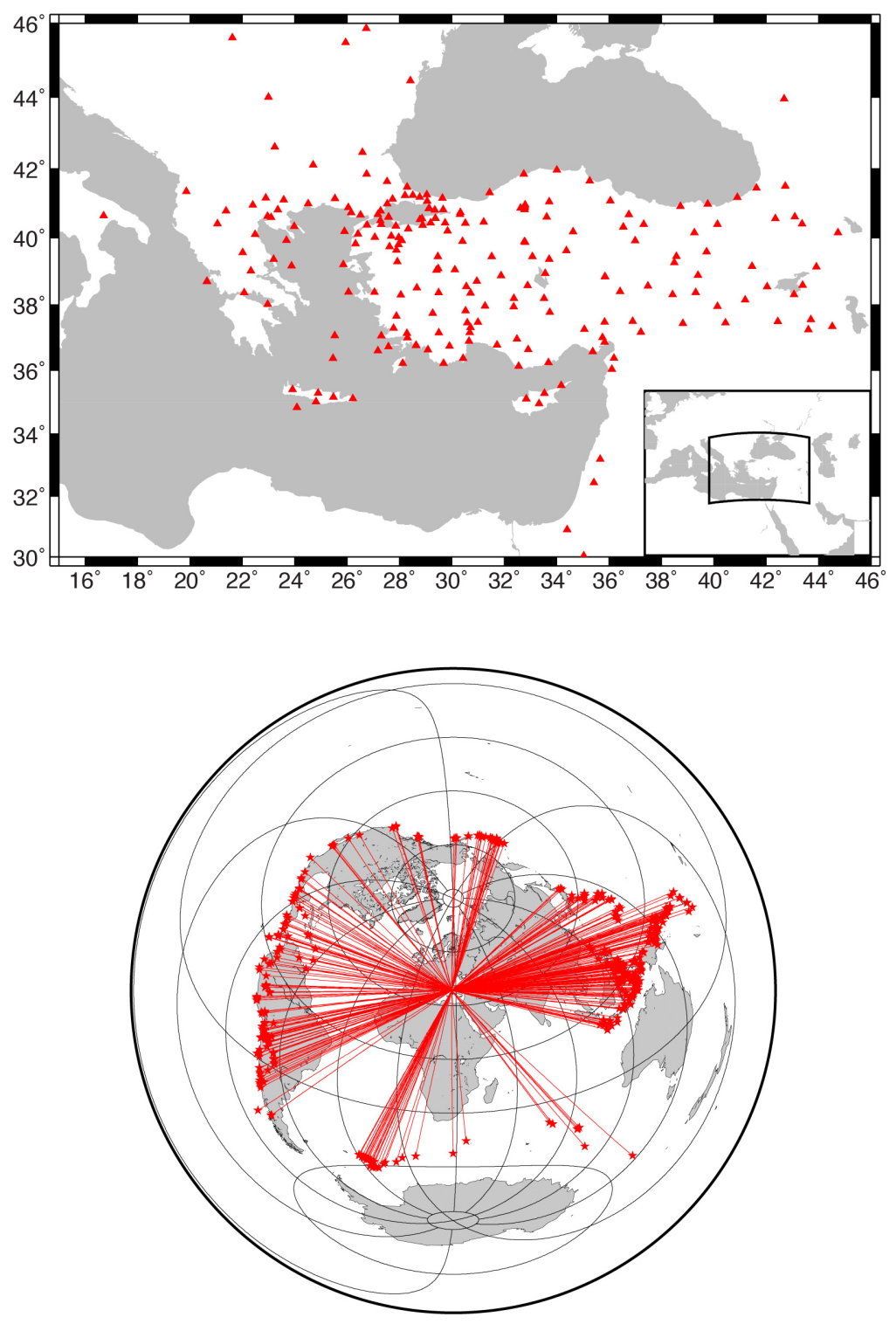

Figure S1: Top: Map of seismic stations where SKS splitting was measured in this study. Bottom: Epicenters of teleseismic events used in our splitting measurements (red-filled stars). The red lines are the great circle paths to the center of the seismic array. The backazimuthal coverage is very heterogeneous, with $80 \%$ of the events being located to the E-NE (backazimuths $50^{\circ}-100^{\circ}$ ) or to the $\mathrm{W}$ of the array (backazimuths $250^{\circ}-300^{\circ}$ ). 


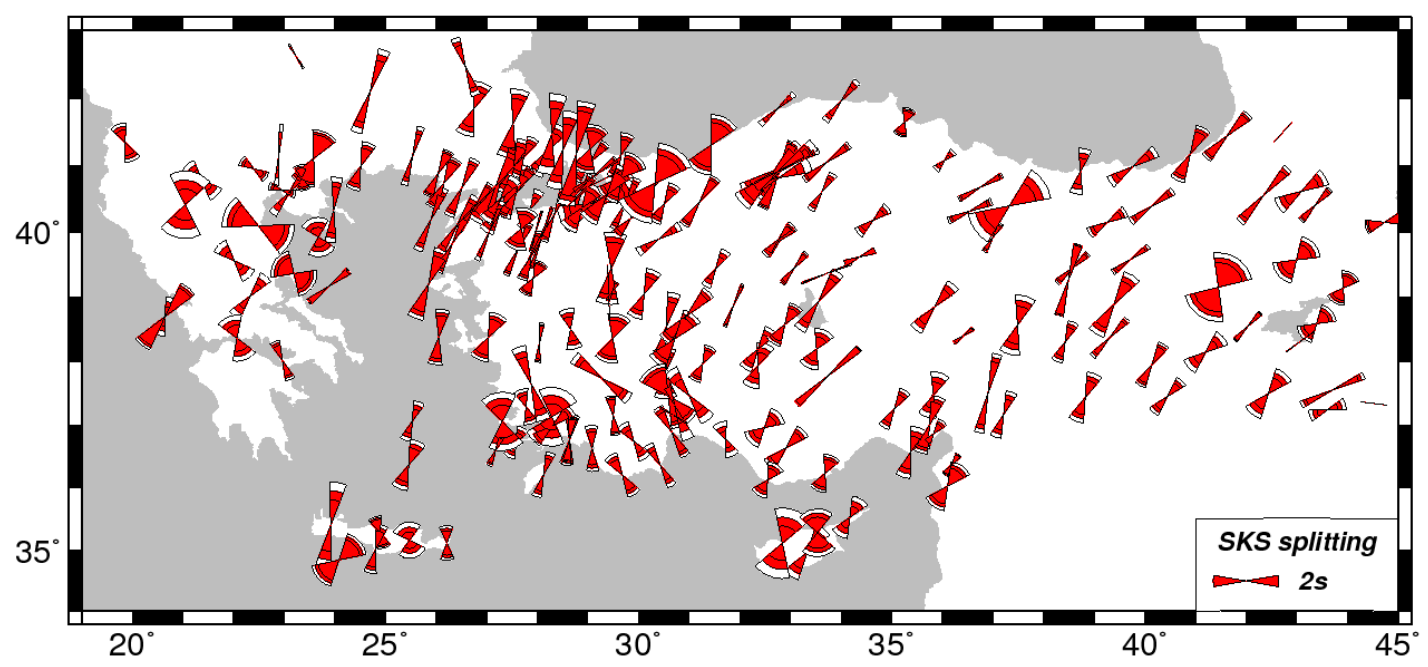

Figure S2: Map of the station-averaged splitting parameters measured in this study, showing standard deviations on the orientation of the fast split wave (as red-filled wedges) and on the time lag (as white-filled sectors).

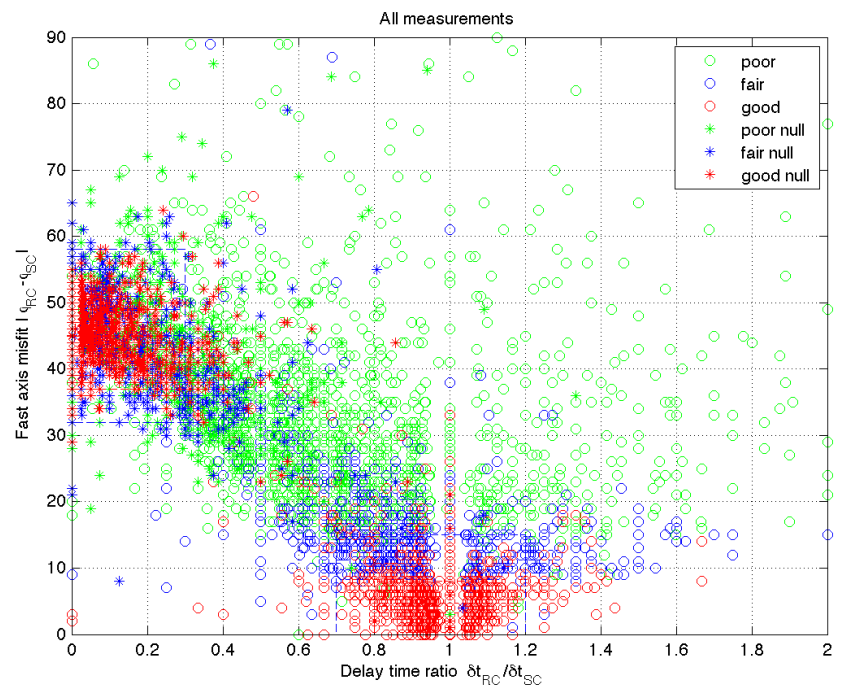

Figure S3: Misfit betwen the splitting parameters measured with the SC (Silver and Chan, 1991) method and the RC (rotation-correlation) method, for all our measurements. According to Wüstefeld et al. (2007), good nulls have fast axis misfits close to $45^{\circ}$ and delay time ratios close to 0 , while good non-null measurements have delay time ratios close to 1 and small fast axis misfits. We used this test of consistency to manually assess the quality of the measurements. 


\section{Station SHUT}
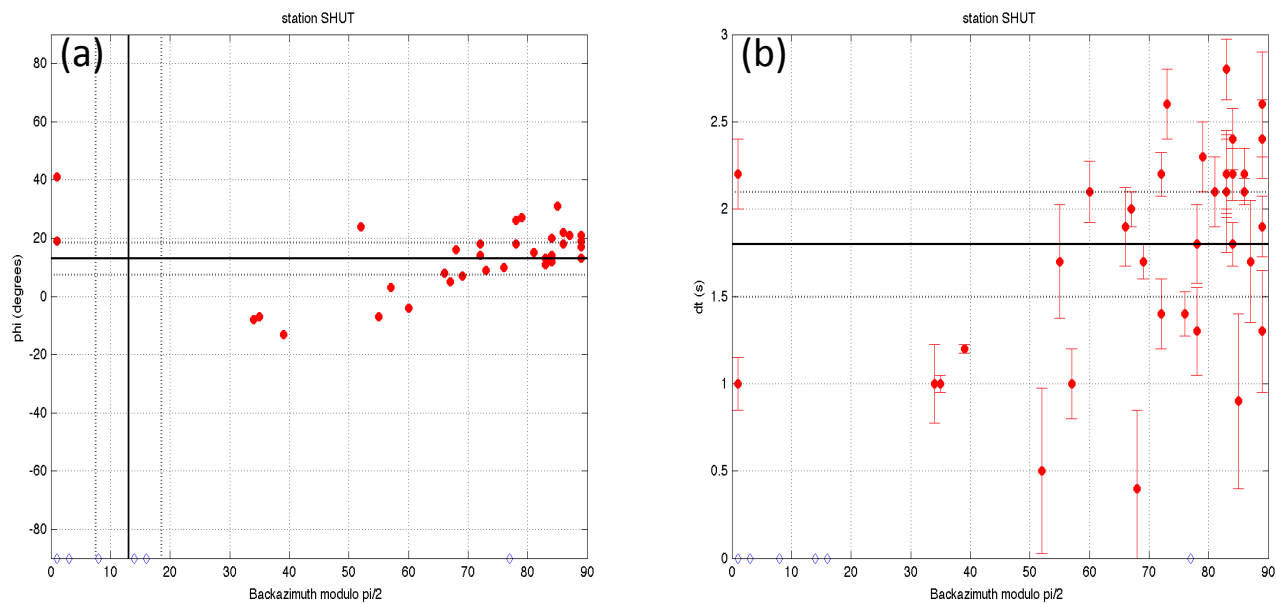

Stations in [39-41N;26-28E]
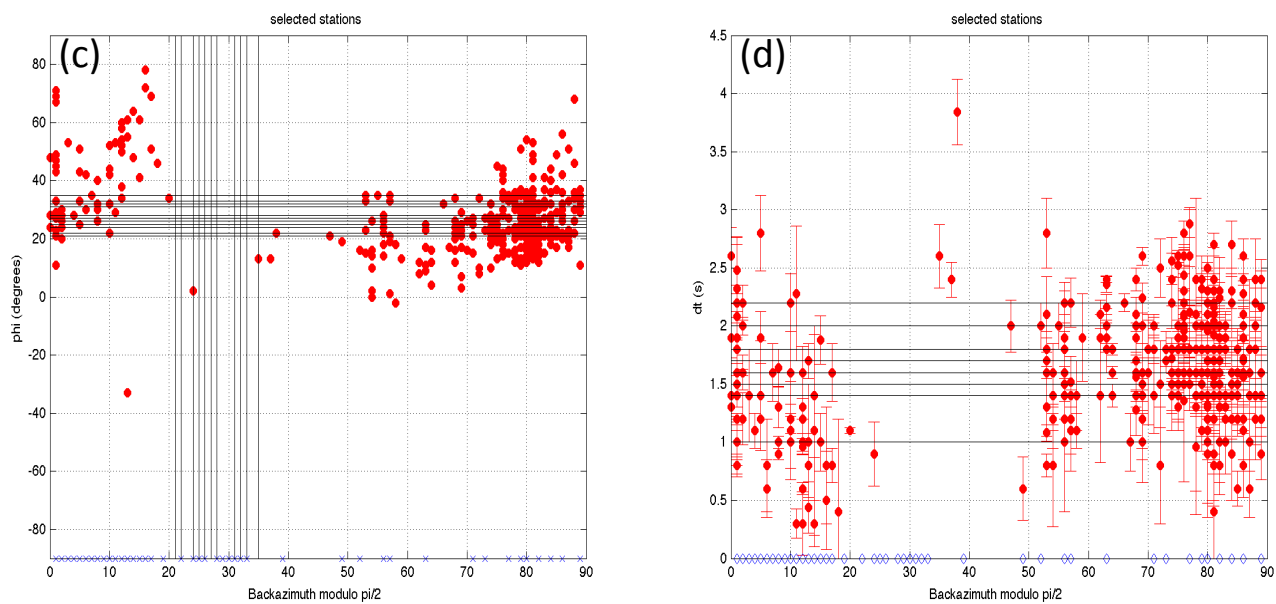

Figure S4: Fast polarization orientations $(a, c)$ and delay times $(b, d)$ plotted with respect to backazimuth (modulo $90^{\circ}$ ) for good and fair measurements at station SHUT (a, b), and at a set of 11 stations of northwestern Anatolia with similar splitting parameters (c, d). Non-null measurements are plotted as filled red circles, while null measurements are shown as open blue diamonds ( $\Phi$ arbitrarily set to $-90^{\circ}$ in a and c). The black lines show the mean splitting parameters for station SHUT (in a and b, with the thin back lines showing the standard deviation), and for the 11 stations in $\mathrm{c}$ and $\mathrm{d}$. At station SHUT, the backazimuthal coverage is too incomplete and the delay time values too scattered to reliably document variations of the splitting parameters with backazimuth, which would indicate depth variable anisotropy. By cumulating data of 11 neighbouring stations (in c and d), the backazimuthal coverage increases and highlights possible systematic variations of $\Phi(\mathrm{c})$. The time delay data are however too scattered to draw any reliable conclusion on depth variations of anisotropy. Null splitting should be measured for backazimuths (modulo $90^{\circ}$ ) close to the mean fast split direction, which is the case for station SHUT but not for the 11 stations. 


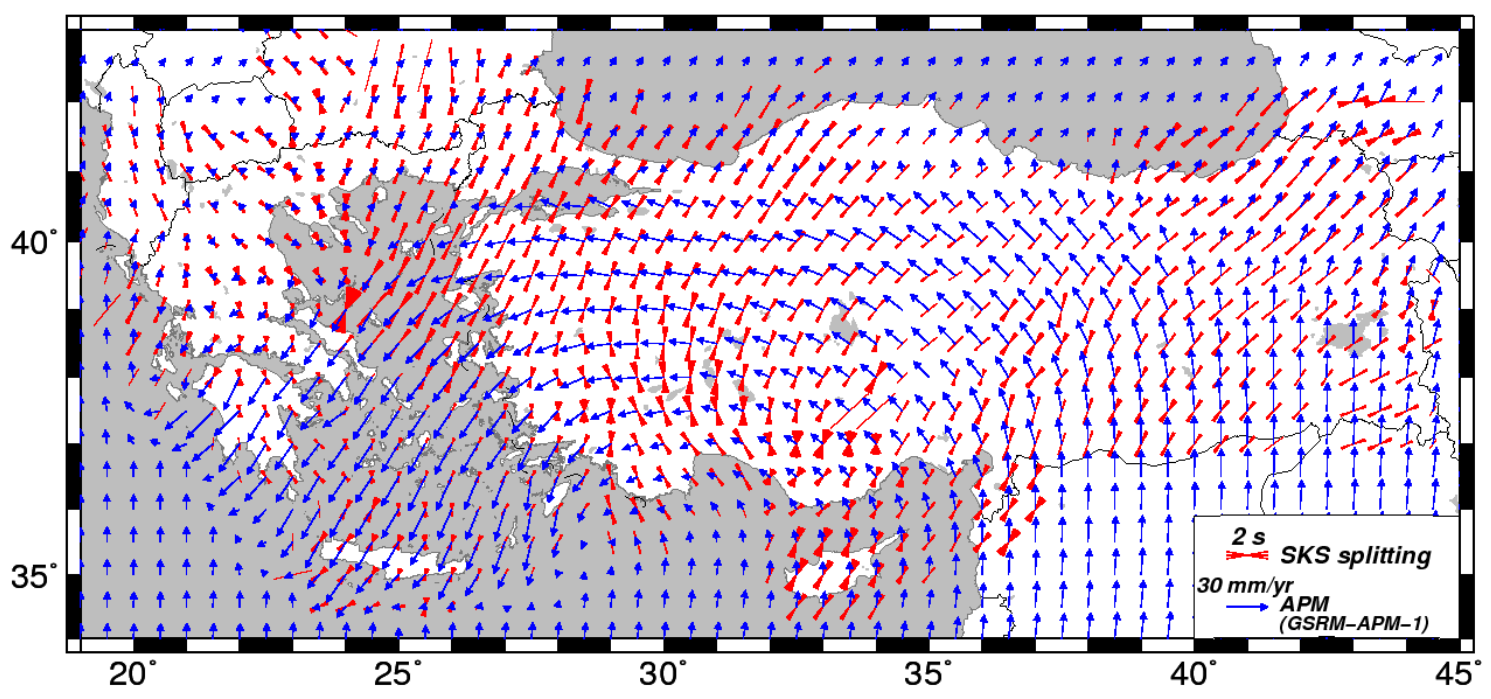

Figure S5: Comparison between our anisotropy parameters projected to $150 \mathrm{~km}$ depth and averaged (red sticks with wedges displaying standard deviation on azimuth), and the absolute plate motion (APM) vectors of the GSRM-APM-1 no net-rotation reference model of Kreemer (2009) (blue vectors).

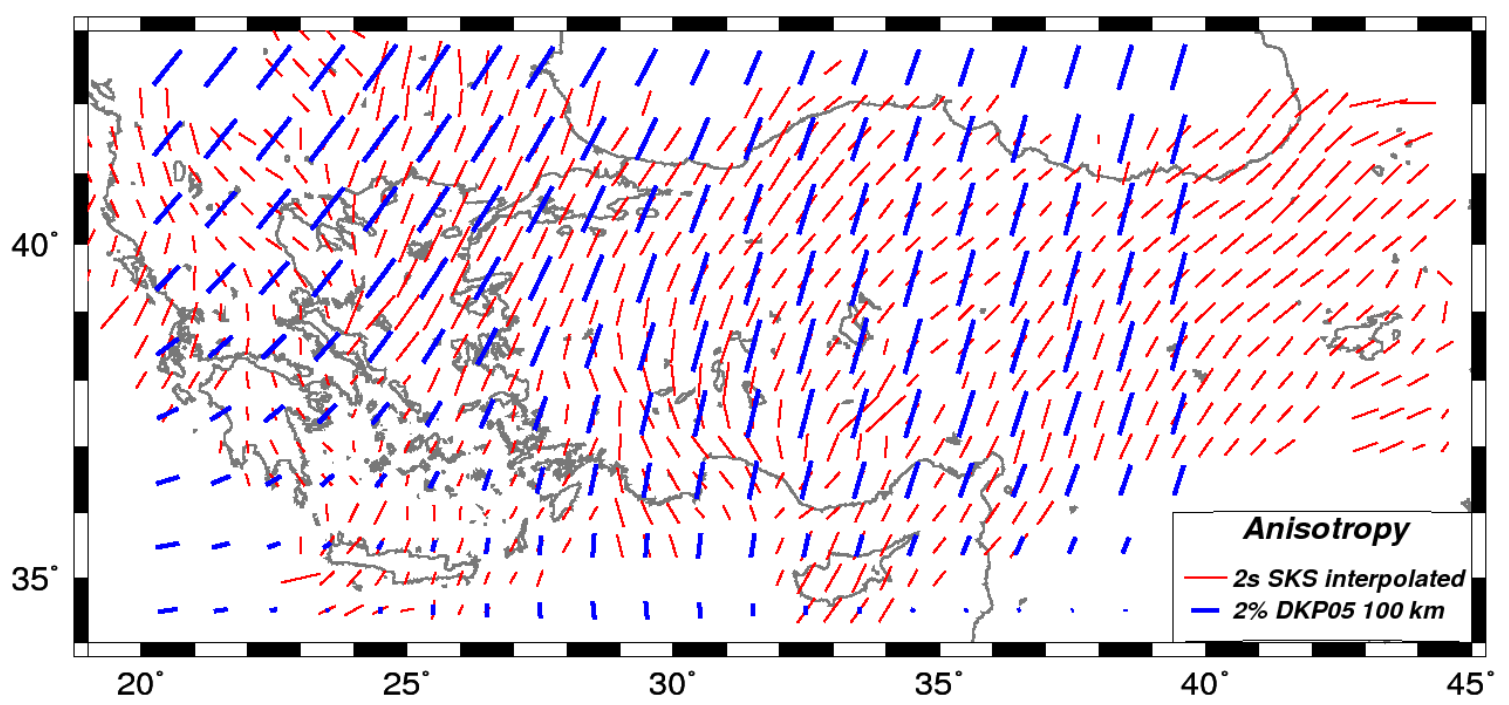

Figure S6: Comparison between our anisotropy parameters projected to $150 \mathrm{~km}$ depth and averaged (red sticks), and the transverse anisotropy at $100 \mathrm{~km}$ depth in the DKP05 global surface-wave model of Debayle et al. (2005) (blue sticks). 